\title{
Differences in meiofauna communities with sediment depth are greater than habitat effects on the New Zealand continental margin: implications for vulnerability to anthropogenic disturbance
}

Norliana Rosli, Daniel Leduc, Ashley A Rowden, Malcolm R Clark, P Keith Probert, Katrin Berkenbusch, Carlos Neira

Studies of deep-sea benthic communities have largely focused on particular (macro) habitats in isolation, with few studies considering multiple habitats simultaneously in a comparable manner. Compared to mega-epifauna and macrofauna, much less is known about habitat-related variation in meiofaunal community attributes (abundance, diversity and community structure). Here, we investigated meiofaunal community attributes in slope, canyon, seamount, and seep habitats in two regions on the continental slope of New Zealand (Hikurangi Margin and Bay of Plenty) at four water depths (700, 1000, 1200 and $1500 \mathrm{~m}$ ). We found that patterns were not the same for each community attribute. Significant differences in abundance were consistent across regions, habitats, water and sediment depths, while diversity and community structure only differed between sediment depths. Abundance was higher in canyon and seep habitats compared with other habitats, while between sediment layer, abundance and diversity were higher at the sediment surface. Our findings suggest that meiofaunal community attributes are affected by environmental factors that operate on micro- $(\mathrm{cm})$ to meso- $(0.1-10 \mathrm{~km})$, and regional scales $(>100 \mathrm{~km})$. We also found a weak, but significant, correlation between trawling intensity and surface sediment diversity. Overall, our results indicate that variability in meiofaunal communities was greater at small scale than at habitat or regional scale. These findings provide new insights into the factors controlling meiofauna in these deep-sea habitats and their potential vulnerability to anthropogenic activities. 


\section{Differences in meiofauna communities with sediment depth}

2 are greater than habitat effects on the New Zealand

3 continental margin: implications for vulnerability to

4 anthropogenic disturbance

5 Norliana Rosli ${ }^{1,2,3}$, Daniel Leduc ${ }^{2}$, Ashley A. Rowden ${ }^{2}$, Malcolm R. Clark ${ }^{2}$, P. Keith Probert ${ }^{1}$, Katrin

6 Berkenbusch ${ }^{1,4}$, Carlos Neira ${ }^{5}$

$7 \quad{ }^{1}$ Department of Marine Science, University of Otago, P.O. Box 56, Dunedin, New Zealand

$8{ }^{2}$ National Institute of Water and Atmospheric Research (NIWA), Private Bag 14-901, Wellington, New

9 Zealand

$10{ }^{3}$ Department of Biology, Faculty Science \& Mathematics, Sultan Idris Education University, $35900 \mathrm{Tg}$.

11 Malim, Perak, Malaysia

$12{ }^{4}$ Dragonfly Data Science, Wellington, New Zealand

$13{ }^{5}$ Integrative Oceanography Division, Scripps Institution of Oceanography, 9500 Gilman Drive, La Jolla, 14 CA 92093-0218, USA

Corresponding Author:

17 Norliana Rosli ${ }^{1}$

18 National Institute of Water and Atmospheric Research (NIWA), 301 Evans Bay Parade, Hataitai, Private 19 Bag 14-901, Wellington 6021, New Zealand

20 Email address: rosli.norliana@gmail.com 
21

22

23

24

25

26

27

Abstract

Studies of deep-sea benthic communities have largely focused on particular (macro) habitats in isolation, with few studies considering multiple habitats simultaneously in a comparable manner. Compared to mega-epifauna and macrofauna, much less is known about habitat-related variation in meiofaunal community attributes (abundance, diversity and community structure). Here, we investigated meiofaunal community attributes in slope, canyon, seamount, and seep habitats in two regions on the continental slope of New Zealand (Hikurangi Margin and Bay of Plenty) at four water depths $(700,1000,1200$ and $1500 \mathrm{~m})$. We found that patterns were not the same for each community attribute. Significant differences in abundance were consistent across regions, habitats, water and sediment depths, while diversity and community structure only differed between sediment depths. Abundance was higher in canyon and seep habitats compared with other habitats, while between sediment layer, abundance and diversity were higher at the sediment surface. Our findings suggest that meiofaunal community attributes are affected by environmental factors that operate on micro- $(\mathrm{cm})$ to meso- $(0.1-10 \mathrm{~km})$, and regional scales $(>100$ $\mathrm{km})$. We also found a weak, but significant, correlation between trawling intensity and surface sediment diversity. Overall, our results indicate that variability in meiofaunal communities was greater at small scale than at habitat or regional scale. These findings provide new insights into the factors controlling meiofauna in these deep-sea habitats and their potential vulnerability to anthropogenic activities.

\section{Introduction}

Continental margins comprise a variety of topographically-defined habitats such as canyons, seamounts and slopes, as well as chemically-defined habitats such as cold seeps and hydrothermal vents (Levin et al. 2010). Canyons are complex topographic features that influence local hydrodynamic regimes, and thus sediment transport and accumulation (García et al. 2008). The resulting changes in physico-chemical characteristics and organic enrichment in the sediments have been linked to high variation in infaunal benthic community structure (Baguley et al. 2006; de Stigter et al. 2007; García et al. 2008; Romano et al. 2013). Seamounts, which are defined as elevated features that include knolls, pinnacles and hills where the elevation can be as low as 100 
m (Clark et al. 2010; Pitcher et al. 2007), can affect surrounding flow conditions resulting in enhanced currents, eddies, up- and down-welling and closed retention cells (Bashmachnikov et al. 2013; White et al. 2007). These modified flow conditions increase vertical mixing, spatial variation in sedimentation processes, and the distribution of food resources (Bongiorni et al. 2013; Levin \& Dibacco 1995; Zeppilli et al. 2013). These and other factors can result in distinct benthic communities on seamounts (Bongiorni et al. 2013; Zeppilli et al. 2014). Cold seeps are characterised by the flow of reduced chemical compounds (e.g. methane, sulphur) from the subsurface to the seafloor (Lampadariou et al. 2013; Levin 2005; Van Gaever et al. 2009). The emission of reduced fluids results in a broad range of geological and sedimentary structures (e.g., gas seepage, microbial mat, pockmarks) (Judd et al. 2002; Levin 2005), which increase small-scale variability in the sediment, thus providing a variety of habitats for infauna that differ from 'background' habitats (Levin \& Mendoza 2007). Hydrothermal vents are localized areas of the seabed where heated and chemically modified seawater exits the seafloor as diffuse or focused flow (Van Dover 2014). Vent ecosystems are typically dominated by benthic invertebrate taxa that host symbiotic, chemoautotrophic microorganisms, and the infauna of hydrothermally 'active' sediments has been shown to differ from that of 'inactive' sediments (Levin et al. 2009).

Meiofauna are the most abundant infauna in deep-sea sediments, with nematodes being the most abundant taxon (Heip et al. 1985; Vanreusel et al. 2010). Studies of meiofaunal communities in the deep sea have focused on canyon and adjacent slope habitats (Bianchelli et al. 2008; Danovaro et al. 2009; Soetaert \& Heip 1995; Soltwedel et al. 2005), and few comparative studies have included seamount (Zeppilli et al. 2013) or cold seep habitats (Pape et al. 2011; Robinson et al. 2004). Vanreusel et al. (2010) provided the first comprehensive comparison of nematode communities among multiple deep-sea habitats (e.g. canyon, seamounts, seep and vent), and showed that different habitats harbour distinct nematode communities and therefore contribute to overall deep-sea nematode diversity.

Although our understanding of meiofaunal community structure of deep-sea habitats is growing, there is remaining uncertainty as meiofauna are not considered in a number of biodiversity studies and are generally poorly studied (particularly in the deep sea) compared to larger macrofauna (Zeppilli et al. 2015). In addition, a more rigorous test of habitat effects on meiofaunal communities requires comparisons that avoid the potential influence of geographical 
distance on community patterns. Knowledge of meiofaunal distribution and connectivity between different habitats is essential for understanding ecological processes, and for assessing the vulnerability of benthic communities to anthropogenic disturbance. There have been concerns about the potential threats of anthropogenic activities on the diversity and function of deep-sea ecosystems (Pusceddu et al. 2014; Ramirez-Llodra et al. 2011; Van Dover 2014), as technological advances make these habitats more accessible (Benn et al. 2010; Levin \& Sibuet 2012). For example, industrial fisheries are expanding and moving into deeper waters (Pitcher et al. 2010; Pusceddu et al. 2014), and seabed mining in the deep sea is expected to begin in the near future (Hein et al. 2013; Ramirez-Llodra et al. 2015).

Physical disruption of habitat by bottom trawling can have pronounced effects on deep-sea soft sediment communities (Pusceddu et al. 2014). Trawling generally has a negative impact on macro-infaunal communities (Hansson et al. 2000; Hinz et al. 2009), whereas studies of meiofauna reveal inconsistent results. To date, studies from shallow water habitats suggest that trawling may have a positive (Liu et al. 2011; Pranovi et al. 2000), negative (Hinz et al. 2008; Schratzberger \& Jennings 2002), or only minor impact (Lampadariou et al. 2005; Liu et al. 2009; Schratzberger et al. 2002) on meiofaunal communities. The only meiofaunal study conducted in the deep sea (Pusceddu et al. 2014) showed a negative effect of trawling on meiofaunal communities. Meiofauna, and nematodes in particular, are generally considered to be more resilient to physical disturbance than larger organisms because they are less likely to be killed and can recover more quickly (Leduc \& Pilditch 2013; Schratzberger et al. 2002; Whomersley et al. 2009). Nevertheless, bottom trawling can also have indirect impacts on sediment communities through the modification of sediment physical characteristics and distribution of organic matter, which can lead to potentially long-term changes in benthic communities (Martín et al. 2014; Pusceddu et al. 2014).

Because of their smaller size, meiofauna tend to respond to micro-scale $(\mathrm{cm})$ variability of environmental conditions in surface and subsurface sediment layers (Ingels et al. 2011a; Ingels et al. 2011b; Soetaert et al. 1997). Ingels \& Vanreusel (2013) showed that most of the variability in nematode community structure occurs at micro $(\mathrm{cm})$ rather than larger spatial scales $(10-100 \mathrm{~km})$. Decline in meiofaunal densities with sediment depth is probably the most pervasive gradient observed in marine sediments (Ingels et al. 2009; Soltwedel et al. 2005; Van Gaever et al. 2006; Vanaverbeke et al. 1997), with the vertical distribution of meiofauna in the sediments mainly 
109 controlled by decreasing food and oxygen availability in subsurface sediments (Giere 2009; Moens

110 et al. 2014; Vanaverbeke et al. 1997; Vanreusel et al. 1995). Meiofaunal diversity is typically

111 highest in surface sediment and decreases in deeper sediments where nematodes become dominant

112 (Danovaro et al. 2002; Schmidt \& Martínez Arbizu 2015). The more abundant and diverse

113 meiofaunal communities of surface sediments are more exposed to disturbance than subsurface

114 communities, and may therefore be affected more by physical disturbance. Studies aiming to

115 uncover the processes driving the composition of deep-sea meiofaunal communities, including

116 potential physical disturbance, should therefore include examination of variation at these smaller 117 scales.

118

119

120

121

122

123

124

125

126

127

128

129

130

131

132

133

134

135

136

The main objectives of this study were to: (1) compare meiofaunal community attributes (abundance, diversity and community structure) in surface $(0-1 \mathrm{~cm})$ and subsurface $(1-5 \mathrm{~cm})$ sediment layers among deep-sea habitats; (2) describe relationships between environmental variables (i.e., water depth, sediment characteristics, topography, food availability), bottom trawling and community attributes of meiofaunal communities; (3) assess the relative vulnerability of meiofaunal communities among habitats, and between surface and subsurface sediment layers.

\section{Material and Methods}

\section{Study area and sampling design}

The study area comprised two regions: Hikurangi Margin and Bay of Plenty of New Zealand (Fig. 1). These two regions were selected because each encompasses a range of benthic habitats within a restricted geographic area, thus facilitating comparisons between associated faunas that were not confounded by distance. The Hikurangi Margin study region is located to the north-east of the South Island, hosts many submarine canyons on its continental slope, and also includes other deep-sea habitats such as seamounts, and cold seeps (Mountjoy et al. 2009; Ruff et al. 2013). The Bay of Plenty study region, located to the north-east of North Island, also includes slope, canyon and seamount habitats, with hydrothermal vents on some seamounts (Wysoczanski \& Clark 2012). The Hikurangi Margin hosts significant fisheries, including hoki (Macruronus novaezelandiae), alfonsino (Beryx splendens) and orange roughy (Hoplostethus altanticus) which occur across all habitats (Clark 1995). This area is also of potential interest for drilling gas hydrate 
137 deposits (Pecher \& Henrys 2003). The Bay of Plenty region is subject to some deep-sea trawl 138 fisheries, including orange roughy, black cardinal fish (Epigonus telescopus) and alfonsino (Beryx 139 decadactylus) (Clark \& O'Driscoll 2003), and is of potential interest for mining of seafloor massive 140 sulphide deposits (Boschen et al. 2013).

141 Sampling sites have been previously described by Bowden et al. (2016). Sampling was 142 conducted at slope, canyon and seamount sites from RV Tangaroa during National Institute of

143

144

145

146

147

148

149

150

151

152

153

154

155

156

157

158

159

160

161

162

163

164

165 Water and Atmospheric Research (NIWA) voyage TAN1004 (April 2010) on the Hikurangi Margin, and voyage TAN1206 (April 2012) in the Bay of Plenty (Fig. 1). The samples were collected under Special Permit (542) issued by the Ministry for Primary Industries pursuant to section 97(1) of the Fisheries Act 1996. Fishing intensity was included as a variable in the analysis (see below) to account for the possible influence of anthropogenic disturbance on the main analysis. Trawl effort data for the period July 1980 to March 2011 were sourced from the trawl database of the New Zealand Ministry for Primary Industries. Sampling was undertaken at four water depth strata $(700,1000,1200$ and $1500 \mathrm{~m})$ at each habitat site to incorporate the effects of water depth in the statistical analyses and provide a more robust evaluation of any habitat effect on community structure. At Hikurangi Margin, meiofauna could not be sampled at some sites/depths, whereas in Bay of Plenty, the limited occurrence of soft sediment prevented the sampling on seamount and vent habitats. The limited data from these sites were not included in the analysis (Table 1). At each sampling station, a towed video camera frame was deployed along transects to ascertain the type of substratum and benthic megafauna before the water column and seafloor was disturbed by sampling gear. Deployment of the multicorer, which targeted soft sediment substrates, was directed based on information from multibeam echo-sounder (MBES) bathymetric maps and observations from the video transects.

Meiofauna samples from seep habitats in the Hikurangi Margin at two sites geographically close to the other habitats sites were obtained from a previous survey in 2006 (voyage TAN0616) (Table 1), and were used in a second-stage analysis comparing seep, canyon, seamount, and slope communities (see below). 
166 surveys, and the results of the analyses of data for these components of the benthos have and will

167 be reported elsewhere (Bowden et al. 2016; Leduc et al. in press). Data on meiofauna are reported 168 here for the first time.

169

170

171

172

173

174

175

176

177

178

179

180

181

182

183

184

185

186

187

188

189

190

191

192

Sampling and sample processing

Meiofauna and sediment samples were collected using an Ocean Instruments MC-800A multicorer (internal diameter core $=9.52 \mathrm{~cm}$ ). At each station, one to three cores were used from each multicorer deployment for meiofaunal samples (refer Table 1), and one core for a sediment sample. Each meiofaunal core was sliced into three vertical fractions: $0-1 \mathrm{~cm}, 1-3 \mathrm{~cm}$ and $3-5 \mathrm{~cm}$ sediment depth layers and preserved in $10 \%$ buffered formalin. Previous analysis showed there was small difference between 1-3 cm and 3-5 cm layers, therefore these layers were combined prior to sieving. Samples were rinsed on a $1 \mathrm{~mm}$ mesh sieve to remove macrofauna and on a 45 $\mu \mathrm{m}$ mesh to retain meiofauna. Meiofauna were extracted from the sieved sediment by Ludox flotation (Somerfield \& Warwick 1996) and were identified to main taxa (e.g. nematodes, nauplii, copepods, annelids) (Higgins \& Thiel 1988) under a stereomicroscope.

The following physical and biogeochemical parameters were determined from the sediment samples: mean particle size (geometric), sorting, skewness, kurtosis, \%silt/clay, particle size diversity (PSD; calculated using Shannon-Wiener diversity index of 11 particle size classes (afterEtter \& Grassle 1992)), calcium carbonate content $\left(\% \mathrm{CaCO}_{3}\right)$, organic matter content $(\% \mathrm{OM})$, organic carbon content $(\% \mathrm{OC})$, nitrogen content $(\% \mathrm{~N})$, chlorophyll $a$ concentration $(\mathrm{chl}$ a) and phaeopigment concentration (phaeo) using methods described by Grove et al. (2006); Nodder et al. (2007); Nodder et al. (2003). The $\% \mathrm{CaCO}_{3}$ was determined from the top $5 \mathrm{~cm}$ of sediment, whereas organic matter $(\% \mathrm{OM}, \% \mathrm{OC}$ and $\% \mathrm{~N})$ was determined from the top $1 \mathrm{~cm}$ of sediment.

\section{Additional environmental characterisation}

The environmental data used in the present study were first published in Bowden et al. (2016). Surface water chlorophyll concentrations were determined using ocean colour estimates of surface chlorophyll concentrations as a proxy for long-term inter-station variability in primary 
193 production

(NASA

SeaWiFS

Project:

194 http://oceandata.sci.gsfc.nasa.gov/SeaWiFS/Mapped/8Day/9km/chlor/). The $9 \mathrm{~km}$ composited

195

196

197

198

199

200

201

202

203

204

205

206

207

208

209

210

211

212

213

214

215

216

217

218

219

220 data of surface chlorophyll were further composited to $90 \times 90 \mathrm{~km}$ pixels centred on the location of each sample station. The mean value for the 1997-2010 period was computed for each station.

Seafloor habitats at the study sites were characterised using seafloor morphology derivatives from MBES data gridded at $25 \mathrm{~m}$ resolution. The following topographic variables were derived for each sampling station: depth, slope (steepest gradient to any neighbouring cell), curvature (change of slope), plan curvature (curvature of the surface perpendicular to the slope direction), and profile curvature (curvature of the surface in the direction of slope). A further set of derivatives was calculated for the standard deviation of depth, depth range, standard deviation of the slope (a proxy measure for slope roughness), and terrain rugosity based on a 3, 5, 7, and 15 grid cell focal means. A total of 18 topographic variables were used in the analysis. Methods for the determined topographic variables are provided by Nodder et al. (2013).

Trawl effort data were used to quantify the extent of commercial fishing intensity conducted on the seafloor in the study regions. Estimates of fishing intensity for a $5 \mathrm{~km} \mathrm{x} 5 \mathrm{~km}$ cell grid covering the New Zealand Exclusive Economic Zone were derived using the number of tows and an estimate of swept area derived from the trawl width and either the distance between start and finish positions, or the tow duration (Black \& Wood 2014). Fishing intensity at each of the study stations was estimated for the total trawled area within the corresponding $5 \mathrm{~km} \times 5 \mathrm{~km}$ cell integrated over a period of ten years prior to sampling.

\section{Statistical analysis}

Statistical analyses were conducted to test the following main hypotheses: that there is no difference in meiofaunal community attributes (abundance, diversity and community structure) in surface $(0-1 \mathrm{~cm})$ and subsurface $(1-5 \mathrm{~cm})$ sediment layers among deep-sea habitats, water depths, and between regions, and that there is no relationship between bottom trawling or environmental variables and meiofaunal community attributes.

Analyses of meiofaunal community attributes (abundance, diversity, and community structure) were conducted using statistical routines in the multivariate software package PRIMER 
221 v6 with PERMANOVA (Anderson et al. 2008; Clarke \& Gorley 2006). Meiofaunal taxon richness

222 was used as the measure of meiofaunal diversity. All analyses were conducted on individual core 223 data.

224

225

226

227

228

229

230

231

232

233

234

235

236

237

238

239

240

241

242

243

244

245

246

247

248

249

250

Analysis of community structure was based on fourth-root transformed abundance data (abundance data per core at each station). Fourth-root transformation was used to reduce contributions to similarity by the numerically dominant nematodes (Somerfield \& Clarke 1995). Similarity matrices for the community structure analysis were built using Bray-Curtis similarity (Clarke \& Gorley 2006). Similarity matrices for meiofauna abundance and diversity were based on Euclidean distance similarity matrices of untransformed data.

The PERMANOVA routine in PRIMER was used to investigate the relative influences of survey region, habitat, water depth strata and sediment depth on community attributes (Anderson et al. 2008). Preliminary analysis showed a significant difference in the abundance of meiofauna between the two regions. Therefore, in addition to a single-factor test for the effect of region (Hikurangi Margin versus Bay of Plenty), and to avoid an overriding influence of abundance on patterns of community structure, analysis testing for the effects of habitat, water depth, and sediment depth were conducted for each region separately. Data were analysed using a four-factor design, with the factors habitat (fixed; canyon, seamount, slope), water depth (fixed; 700, 1000, 1200, $1500 \mathrm{~m}$ ), sediment depth (fixed; 0-1 and 1-5 cm), and cores (random, nested within habitat and water depth strata). P-values for individual predictor variables were obtained using 9999 permutations. Lack of independence between stations due to geographical proximity (i.e. spatial autocorrelation/structure) is common in natural communities and poses limitations for the interpretation of ecological patterns (Legendre 1993). In particular, failure to take into account the spatial component of ecological variation may affect tests of statistical significance when investigating relationships between community structure and environmental parameters (Legendre \& Troussellier 1988). Therefore, latitude and longitude were fitted first in the models of community structure to account for the effect of geographical proximity. The main factor test was followed by pair-wise tests when significant effects were found. The square-root value of estimates of components of variation ( $\mathrm{VECV}$ ) was used to compare the relative strengths of significant factor effects. A non-metric multi-dimensional scaling plot (MDS) was used to visualise patterns in multivariate community structure. The SIMPER routine was used to identify which taxa were 
251 responsible for any habitat, region, water depth strata and/or sediment-related differences in 252 community structure. SIMPER was also used to identify the main environmental variables 253 responsible for differences between regions. This analysis was conducted on similarity matrices 254 built using normalised environmental data and the Euclidean similarity measure; topographical 255 variables were not included because slope, canyon, and seamount habitats are defined a priori as 256 topographical features.

257

The DistLM routine was used to investigate the relationship between meiofaunal community attributes and environmental variables. The full set of environmental variables was partitioned into five sets, i.e., spatial (water depth), sediment characteristics (mean particle size, sorting, skewness, kurtosis, \%silt/clay, $\mathrm{PSD}, \% \mathrm{CaCO}_{3}, \% \mathrm{OM}, \% \mathrm{~N}, \% \mathrm{OC}$, chl $a$, phaeopigment), primary productivity (surface chlorophyll concentration), fishing intensity, and topography variables (18 variables). Environmental variables that were strongly correlated $(r>0.8)$ were removed prior to analysis (Table S1). Relationships between environmental parameters and community attributes were initially examined by analysing each predictor separately (marginal tests). Partial regressions were used to better characterise the relationships and to account for the effect of the remaining variables. Sequential tests were conducted using step-wise selection procedures and $\mathrm{R}^{2}$ as the selection criterion. Latitude and longitude were fitted first in the models of community structure to account for the effect of geographical proximity. P-values for individual predictor variables were obtained using 9999 permutations.

Meiofaunal community data from slope, canyon, and seamount habitats in Hikurangi Margin (from TAN1004) were compared to those for seep meiofauna in a second-stage analysis. Stations from the two seep sites were available from 1049-1059 m water depths (Table 1), thus only data from the depth strata of, and closest in depth to, these sites were included in the analysis (i.e. the $1500 \mathrm{~m}$ stratum was excluded). The effects of habitat and sediment depth on meiofaunal community attributes were compared using PERMANOVA. MDS and SIMPER routines were conducted as described above. 


\section{Results}

278

279

280

281

282

283

284

285

286

287

288

289

290

291

292

293

294

295

296

297

298

299

300

301

302

In total, 15 meiofaunal taxa were identified from the samples. The most abundant taxon was nematodes $(87.1 \%$ of total abundance), followed by copepods $(6.0 \%)$, nauplii $(4.2 \%)$ and annelids (1.4\%). The abundance of each of the remaining taxa (e.g. ostracods, kinorhynchs, isopods, tanaidaceans, amphipods, gastrotrichs, loriciferans, tardigrades, bivalves, cumaceans, aplacophorans) was less than $0.8 \%$ of total meiofaunal abundance.

\section{Comparison of Hikurangi Margin and Bay of Plenty regions}

SIMPER analysis of environmental variables showed substantial variability between regions, mostly in surface water chlorophyll concentration, sediment phaeopigment concentration, organic carbon content of the sediment and fishing intensity (Table S2). These four variables were substantially higher in the Hikurangi Margin than in the Bay of Plenty (Fig. 2). Surface water chlorophyll concentrations and organic carbon content were two times higher, and sediment phaeopigment concentration five times higher, in the Hikurangi Margin than in the Bay of Plenty. Mean fishing intensity was 30 times greater in the former region, but among-site variability was high.

There was a significant difference in meiofaunal abundance between regions (PERMANOVA, $\mathrm{P}=0.0001$ ). Average meiofaunal abundance was higher in the Hikurangi Margin $\left(1481 \pm 538\right.$ individual $\left.10 \mathrm{~cm}^{-2}\right)$ compared to the Bay of Plenty $(929 \pm 396)$. There was a small but significant difference in meiofaunal diversity (meiofaunal taxon richness) between regions (PERMANOVA, $\mathrm{P}=0.04$ ), with a total of 12 major taxa identified in the Hikurangi Margin region (average diversity: 7 taxa per core), which was less than the 14 major taxa identified in the Bay of Plenty region (average diversity: 6 taxa per core).

Meiofaunal community structure was significantly different between regions (PERMANOVA, $\mathrm{P}=0.0001$; Fig. 3). Kinorhynchs were the greatest contributor to between-region dissimilarity, and like most other meiofaunal taxa, their average abundance was higher in the Hikurangi Margin region than in the Bay of Plenty (Table 2). Tardigrades, gastrotrichs and 
303 loriciferans were only recorded in the Bay of Plenty, whereas bivalves were only recorded in the 304 Hikurangi Margin.

305

306

307

308

309

310

311

312

313

314

315

316

317

318

319

320

321

322

323

324

325

326

327

328

329

330

\section{Hikurangi Margin}

Meiofaunal abundance differed significantly among habitats, water depths, and sediment depths in the Hikurangi Margin study region (PERMANOVA, P < 0.05; Fig. 4; Table S3). Interactions between sediment depth and all the other factors were also significant, indicating that patterns were not consistent between surface and subsurface layers. Pairwise comparisons showed significantly lower abundance of surface $(0-1 \mathrm{~cm})$ meiofauna on seamounts relative to canyons, while subsurface $(1-5 \mathrm{~cm})$ meiofaunal abundance was significantly lower on seamounts than in both canyon or slope habitats. Pairwise comparisons also showed significantly higher abundance of surface and subsurface meiofauna at $700 \mathrm{~m}$ water depth than deeper depths (surface layer: 1200 and $1500 \mathrm{~m}$, subsurface layer: 1000, 1200 and $1500 \mathrm{~m}$ ). Comparing the estimates of components of variation showed that sediment depth (89.0) and habitat (86.8) explained similar proportions of variability in abundance, whilst water depth explained a smaller proportion (57.4) (Table S3). Diversity differed significantly between sediment depths, but not among habitats or water depths (PERMANOVA, $\mathrm{P}<0.05$; Table S4), and higher in surface than in subsurface sediments.

Meiofaunal community structure differed significantly between sediment depths, but not among habitats or water depths (PERMANOVA, $\mathrm{P}=0.0001$; Fig. 5; Table S5). SIMPER analysis showed average community dissimilarity between the $0-1 \mathrm{~cm}$ and $1-5 \mathrm{~cm}$ sediment depth was $24.2 \%$; nauplii were the largest contributor to community dissimilarity $(16.8 \%$ of total dissimilarity) (Table 3). Average abundance of nematodes, annelids, and isopods was higher in the 1-5 cm than the $0-1 \mathrm{~cm}$ sediment depth layer, whereas the other meiofaunal taxa showed the opposite trend.

Results of DistLM analyses showed that abundance in the $0-1 \mathrm{~cm}$ sediment layer was significantly correlated with profile curvature and water depth $\left(\mathrm{P}<0.05 ; \mathrm{R}^{2}=0.12\right.$; Table 4; Fig. 6). Abundance in surface sediment was negatively correlated with profile curvature, indicating that abundance was greater in depressions than on elevated topography, whereas the relationship between abundance and water depth was positive. Meiofaunal abundance in the $1-5 \mathrm{~cm}$ layer was 
331 significantly and positively correlated with the standard deviation of the slope (15 grid cell focal

332 mean; a proxy measure for slope roughness), and sediment phaeopigment concentration $(\mathrm{P}<0.05$;

$\left.333 \mathrm{R}^{2}=0.24-0.41\right)$. Abundance in subsurface sediment was also negatively correlated with water

334 depth $\left(\mathrm{P}<0.05 ; \mathrm{R}^{2}=0.19 ;\right.$ Table 4$)$.

335 Meiofaunal diversity in the $0-1 \mathrm{~cm}$ sediment layer was significantly and negatively 336 correlated with mean particle size, particle size diversity and fishing intensity $\left(\mathrm{P}<0.05 ; \mathrm{R}^{2}=0.07\right.$;

337 Table 4; Fig. 7). Diversity in the 1-5 cm sediment layer was significantly and negatively correlated 338 with both curvature and profile curvature $\left(\mathrm{P}<0.05 ; \mathrm{R}^{2}=0.13-0.16\right)$, indicating that diversity was 339 greater in depressions than on elevated topography.

Meiofaunal community structure in the $0-1 \mathrm{~cm}$ sediment layer was significantly correlated with profile curvature, curvature and water depth $\left(\mathrm{P}<0.05 ; \mathrm{R}^{2}=0.05-0.08\right.$; Table 4$)$, whilst

342 community structure in the 1-5 cm sediment layer was significantly correlated with curvature and 343 phaeopigment concentration in the sediment.

Meiofaunal abundance differed significantly among habitats, water depth, and sediment depths in the Bay of Plenty study region; there was also a significant interaction between habitat and water depth (PERMANOVA, P $<0.05$; Table S3; Fig. 4). Pairwise comparisons only showed a significant interaction at $1200 \mathrm{~m}$, but not at other water depths, where higher abundance of meiofauna were observed in canyons relative to slopes. Comparing the estimates of components of variation showed that habitat explained a greater proportion of the variability in abundance than sediment depth and water depth (Table S3). Diversity differed significantly between sediment depth, but not among habitats or water depths (PERMANOVA, P < 0.05; Table S4), and higher in surface than in subsurface sediments.

Meiofaunal community structure differed significantly among water depths and between sediment depths, but not among habitats (PERMANOVA, P < 0.05; Fig. 5; Table S5). Comparing the estimates of components of variation showed that sediment depth explained a greater proportion of the variability in abundance than water depth (Table S5). Pairwise comparisons showed that community structure differed significantly between $700 \mathrm{~m}$ and $1200 \mathrm{~m}$, and between 
$359700 \mathrm{~m}$ and $1500 \mathrm{~m}$. SIMPER analysis showed average community dissimilarity between $700 \mathrm{~m}$ 360 and $1200 \mathrm{~m}$, and between 700 and $1500 \mathrm{~m}$ depth, was $\sim 24 \%$. SIMPER results showed that nauplii 361 were the main contributor to community dissimilarity, and that the average abundance of all 362 meiofaunal taxa was higher at $700 \mathrm{~m}$ than at 1200 and $1500 \mathrm{~m}$ water depths (Table 5). Average 363 community dissimilarity between $0-1 \mathrm{~cm}$ and $1-5 \mathrm{~cm}$ sediment depths was $26.3 \%$. SIMPER 364 results showed that nauplii were the main contributor to community dissimilarity, and that 365 nematode average abundance was higher in the $1-5 \mathrm{~cm}$ than the $0-1 \mathrm{~cm}$ sediment depth, whereas 366 the other meiofaunal taxa showed the opposite trend (Table 5).

367 Results of DistLM analysis showed that abundance in the $0-1 \mathrm{~cm}$ sediment layer was 368 significantly correlated with surface water chlorophyll concentration, sediment carbonate content 369 and plan curvature $\left(\mathrm{P}<0.05 ; \mathrm{R}^{2}=0.09\right.$; Table 6). The relationship between abundance and 370 sediment carbonate content was negative, whereas abundance was positively correlated with 371 surface water chlorophyll concentration and plan curvature (Fig. 6). The positive relationship 372 between plan curvature and abundance indicated that abundance was greater in elevated 373 topography perpendicular to the slope direction. Abundance in the $1-5 \mathrm{~cm}$ sediment layer was 374 significantly and positively correlated with organic carbon content, kurtosis, and phaeopigment 375 concentration in the sediment $\left(\mathrm{P}<0.05 ; \mathrm{R}^{2}=0.07-0.18\right.$; Table 6; Fig. 6). water chlorophyll concentration and water depth $\left(\mathrm{P}<0.05 ; \mathrm{R}^{2}=0.09-0.1\right.$; Table 6; Fig. 7). The relationship between diversity and surface water chlorophyll concentration was positive, whereas diversity was negatively correlated with water depth. Diversity in the $1-5 \mathrm{~cm}$ sediment layer was significantly and positively correlated with kurtosis and organic carbon content $\left(\mathrm{P}<0.05 ; \mathrm{R}^{2}=\right.$ 381 0.09-0.15).

Meiofaunal community structure in the $0-1 \mathrm{~cm}$ sediment layer was significantly correlated with water depth and surface water chlorophyll concentration $\left(\mathrm{P}<0.05 ; \mathrm{R}^{2}=0.04\right.$; Table 6). Community structure in the $1-5 \mathrm{~cm}$ sediment layer was significantly correlated with kurtosis, silt and clay particle content, and particle skewness $\left(\mathrm{P}<0.05 ; \mathrm{R}^{2}=0.05-0.06\right)$. 
386

387

388

389

390

391

392

393

394

395

396

397

398

399

400

401

402

403

404

405

406

407

408

409

410

411

412

Slope, canyon, and seamount habitats compared to seep habitat: Hikurangi Margin

The second-stage analysis of slope, canyon, seamount, and seep communities in the Hikurangi Margin showed a significant effect of habitat, sediment depth, and their interaction, on abundance (PERMANOVA, $\mathrm{P}<0.05$ ). Pairwise comparisons only showed a significant interaction between canyons and seeps at subsurface sediment $(1-5 \mathrm{~cm})$, where abundance was higher in canyon than seep habitats (Table S6). Diversity differed significantly among habitats and between sediment depths (PERMANOVA, $\mathrm{P}<0.05$ ). Differences in diversity were small, but overall diversity was significantly higher in seep habitat (average diversity $=7.2$ ) compared to the other habitats $($ canyon $=5.9$, slope $=6.0$, seamount $=5.4)$, and was significantly higher in surface sediment (6.6) than in subsurface sediment (5.7).

Meiofaunal community structure differed significantly among habitats and between sediment depths (PERMANOVA, $\mathrm{P}<0.05$; Table S7). Pairwise comparisons showed that meiofaunal communities differed significantly $(\mathrm{P}<0.05)$ between seep and all of the other habitats, which did not differ significantly from each other (Fig. 8). Nauplii and amphipods contributed the most to community dissimilarity (12-15\% of total dissimilarity) between seeps and the other habitats (Table 7). Average abundance of meiofaunal taxa was higher in seep habitats than in the other habitats, except for kinorhynchs, ostracods and nematodes which were most abundant in canyon and slope habitats.

\section{Discussion}

Knowledge of the benthic communities associated with distinct habitats in the deep sea has increased significantly during the last decades, as we now have a better understanding of how substrate type and availability, biogeochemistry, nutrient input, productivity, hydrographic conditions and catastrophic events shape community patterns on regional scales (Levin et al. 2010; Vanreusel et al. 2010). In this study, meiofaunal community attributes differed between regions and sediment depths, and between habitats and water depths for some community attributes. Relationships between environmental variables, trawling intensity, and community attributes also differed between surface and subsurface sediment communities. The patterns observed are 
413 discussed below in relation to potential environmental drivers, as is the relative vulnerability of

414 meiofaunal communities to anthropogenic activities.

415

416

417

418

419

420

421

422

423

424

425

426

427

428

429

430

431

432

433

434

435

436

437

438

439

440

441

Regional differences in meiofaunal communities

The flux of organic matter from the surface to the seafloor is the main driver of meiofaunal benthic abundance (Lambshead et al. 2002; Soltwedel 2000). Meiofaunal density has often been linked to food availability in the sediment (Ingels et al. 2009; Lampadariou \& Tselepides 2006; Leduc et al. 2014), with high food concentrations associated with high numbers of individuals. The greater abundance of meiofauna in the Hikurangi Margin relative to the Bay of Plenty appeared to be related to differences in surface water chlorophyll concentrations. The latter corresponded with phaeopigment concentrations and organic carbon content of the sediment, indicating increased food availability in the Hikurangi Margin than in the Bay of Plenty region. It is likely that this higher food availability led to the observed differences in meiofaunal abundance. There was a clear difference in meiofaunal community structure between regions. Most taxa were more abundant in the Hikurangi Margin compared to the Bay of Plenty, except for certain rare taxa (e.g., gastrotrichs, tardigrades, loriciferans, bivalves) that were only present in one of the regions.

Trawling activity can have pronounced effects on meiofaunal communities (Pusceddu et al. 2014; Schratzberger et al. 2009), and could also be responsible for regional differences in community attributes in the present study. Although there was only a weak correlation between trawling intensity and diversity in surface sediments, it is possible that trawling impacts on environmental variables may have affected diversity. For example, trawling has been shown to alter sediment physical characteristics and the distribution of organic matter in the sediment column, through continuous stirring of the upper sediments which leads to removal of recent organic-rich sediment and induced changes in the grain size distribution, as repeated resuspension of the remaining sediments favours the sorting of particles according to their settling speeds (Martín et al. 2014; Pusceddu et al. 2014). In the present study, we found a negative relationship between mean particle size and particle size diversity and meiofaunal diversity in the surface sediment of the Hikurangi Margin, which contrasts with the findings of previous studies showing the opposite pattern (Etter \& Grassle 1992; Leduc et al. 2012). This discrepancy may be explained by the impacts of trawling, which could increase mean sediment particle size and sediment particle 
442 size diversity while at the same time decreasing diversity through increased dominance of

443 opportunistic genera (Pusceddu et al. 2014; Schratzberger et al. 2009). However, identifying 444 potential impacts of trawling at the regional scale will require further research.

445

446

447

448

449

450

451

452

453

454

455

456

457

458

459

460

461

462

463

464

465

466

467

468

469

470

\section{Among-habitat differences in meiofaunal communities}

Meiofaunal abundance differed among the deep-sea habitats studied, which was evident in both of the study regions. The first-stage analysis showed that abundance was higher in canyons than in other habitats of both regions. Abundance also differed between water depths in both study regions, with total meiofaunal abundance consistently higher in the shallower strata.

In the Hikurangi Margin region, profile curvature and water depth were the two factors most strongly correlated with abundance in the surface sediment. Greater meiofaunal abundance in seafloor depressions could be associated with greater settlement of meiofauna associated with slower near-bottom water currents in depressions (Fleeger et al. 1995; Giere 2009). Negative profile curvatures were mostly found in canyon habitat (see Fig. 6), which is well known for their complex topography (Canals et al. 2006), and could partly explain the observed canyon habitat effect. In addition, abundances for surface sediments were positively correlated with water depth in all habitats. Higher abundance at deeper sites could result from high settlement of meiofauna that was passively transported downslope by currents; even weak currents can re-suspend meiofaunal organisms and transport them long distances down continental margins (Boeckner et al. 2009; Pusceddu et al. 2014). Higher abundance could also be related to increase in food availability at deeper depths observed in this study, which may result from downslope transport of fine organic matter (Pusceddu et al. 2014; Weaver et al. 2000).

In the Bay of Plenty region, other environmental variables influenced meiofaunal abundance. In the surface sediment, surface chlorophyll concentration and plan curvature were positively correlated with abundance. Surface water chlorophyll concentration can be considered an indicator of the flux of organic matter and phytodetritus to the sea floor, and thereby the availability of food to benthic organisms (Rex \& Etter 2010). In the present study, surface water chlorophyll concentrations corresponded with higher meiofaunal abundance at the canyon sites, and previous studies support this finding (Baguley et al. 2006; Ingels et al. 2009; Pusceddu et al. 2009; Soltwedel 2000). The positive relationship between plan curvature and abundance was 
471 contrary to the findings in the Hikurangi Margin which showed a negative relationship with

472 curvature and profile curvature, and suggests that abundance is not always greatest in seafloor 473 depressions. Sun \& Fleeger (1994) showed that recolonization processes and abundance patterns 474 of meiofauna depend on the interaction between the hydrodynamic regime associated with seafloor 475 depressions and the life style of meiofauna (e.g. epibenthic or burrowers), and it is possible that 476 similar interactions influence the abundance patterns of meiofauna in this study region, resulting 477 in different patterns between regions. However, the lower level of taxonomic resolution used in 478 this study prevented further analysis to confirm this result.

The second-stage analysis showed that meiofaunal abundance, diversity and community

480

481

482

483

484

485

486

487

488

489

490

491

492

493

494

495

496

497

498

499

500 structure at seep habitats were significantly different from the other habitats in the Hikurangi Margin and the differences in community structure were due to variation in the relative abundances of a large number of taxa rather than the presence or absence of unique taxa. Overall abundance was higher at the seep habitat compared with the other habitats, with nauplii and amphipods contributing most to community dissimilarity. High densities at seep sites compared with the adjacent slope habitat have also been observed previously, and have mainly been due to elevated abundances of nematodes and copepods (Pape et al. 2011; Shirayama \& Ohta 1990; Van Gaever et al. 2006; Vanreusel et al. 2010). In the present study, the high abundance of copepods and nauplii at cold seeps was opposite to the pattern observed by Van Gaever et al. (2009), where low abundances of copepods and nauplii were observed, and kinorhynchs, polychaetes, and gastrotrichs were more abundant. Similarly, the high abundance of nematodes, kinorhynchs and ostracods in canyon and slope habitat compared with seep habitat was different to patterns observed elsewhere (Van Gaever et al. 2006). Priapulid larvae were only observed in the seep habitat in the Hikurangi Margin, and the reason for this observed pattern remains unclear. In the present study, diversity was higher in the seep compared with other habitats, which were similar to each other. This finding is similar to Bianchelli et al. (2010), where canyons and slopes were equally diverse, but opposite to other studies where seep diversity was lower than canyon and slope habitats (Ingels et al. 2009; Van Gaever et al. 2009).

Our results support the general findings that there is an effect of seeps on meiofaunal abundance, diversity and community structure (Lampadariou et al. 2013). Higher meiofaunal abundance at seeps has been attributed to high food availability, resulting from methane seepage 
501 fuelling bacterial productivity (Van Gaever et al. 2006); a number of nematode and copepod 502 species are adapted to exploiting bacteria in sediment patches with high methane levels (Zeppilli 503 et al. 2011). In addition, a broad range of geological and sedimentary structures (e.g., gas seepage, 504 microbial mat, pockmarks), and seep epifauna generate habitat (e.g., tubeworms, mussels, clams), 505 resulting in habitat heterogeneity, both above and below the sediment surface (Judd et al. 2002; 506 Levin 2005). This habitat heterogeneity is likely to be a key reason for the relatively high diversity 507 in seep habitats in the Hikurangi Margin, where microbial mats, sediment patches contained 508 methane/hydrogen sulphide, clam beds, and carbonate structures have been observed (Baco et al. 509 2010). Increased microhabitat heterogeneity at seeps compared to other adjacent deep-sea habitats 510 provides a broad array of geophysical environments including those that some fauna are

511 particularly adapted to, such as nematodes that occur in the oxygenated sediment underneath 512 siboglinid tubeworm patches (Vanreusel et al. 2010). Each seep site is unique with different 513 geophysical structure, and thus the influence of the seepages on benthic biodiversity is likely to be 514 site-specific (Zeppilli et al. 2012). This proposition could explain the different responses of 515 meiofaunal taxa in our study to those in previous studies (Pape et al. 2011; Van Gaever et al. 2009; 516 Van Gaever et al. 2006).

\section{Meiofaunal community attributes in surface and subsurface sediment layers}

The magnitude of sediment depth-related differences in meiofaunal community attributes was substantially greater than for habitats or water depths. This finding is consistent with Ingels \& Vanreusel (2013) who observed that variability in meiofaunal communities between sediment depth layers was much greater than variability observed at larger geographical scales (10-100 km).

Meiofaunal abundances were much higher in the surface than the subsurface layer of the sediments, except for nematodes which showed the opposite trend. These results are comparable with findings from other meiofaunal studies, where abundance decreased with sediment depth, and where nematodes become the dominant taxon at subsurface depths (Danovaro et al. 2002; Ingels et al. 2009; Neira et al. 2001). In the Hikurangi Margin region, the differences in the abundance in surface and subsurface sediment layers were greater between canyon and seamount habitats, and between shallow and deep sites. This result may be explained by the complex hydrodynamic regime associated with canyons that can affect the deposition and accumulation rates of sediments 
530 and organic matter, resulting in a pronounced structuring of the sediment column within the

531 canyon. Abundance in surface sediment increased with water depth, while abundance in 532 subsurface sediment decreased with water depth, a pattern similar to that observed by Vanaverbeke 533 et al. (1997). These authors argued that the low input of organic matter at the deeper sites, as well 534 as shallow penetration of organic matter in the sediment due to lower bioturbation, could explain 535 this pattern (Vanaverbeke et al. 1997).

Different factors may be driving variation in the abundance of surface and subsurface meiofaunal communities in different regions. In the Hikurangi Margin, seafloor depressions apparently contributed to higher abundance in surface sediment than on flat or elevated ground,

539 by reducing current flow and helping deposition and meiofauna settlement (Fleeger et al. 1995; 540 Giere 2009). Changes in hydrodynamic conditions around seabed features may also affect larval 541 settlement and sediment grain size characteristics (Butman 1987; McClain \& Barry 2010). In the 542 subsurface sediments, abundance was positively correlated with sediment phaeopigment 543 concentration and standard deviation of the slope (a proxy measure for slope roughness). Enhanced 544 food availability in the sediment, as indicated by elevated phaeopigment concentrations derived 545 from surface water productivity, has frequently been shown to support higher meiofaunal 546 abundance (Ingels et al. 2009; Pusceddu et al. 2009). It remains unclear how slope roughness is 547 likely to influence meiofaunal abundance in subsurface sediment.

548 In the Bay of Plenty, abundance was positively influenced by surface chlorophyll 549 concentration and plan curvature in the surface sediments. In the subsurface sediment, abundance 550 was positively related with both sediment organic carbon content and kurtosis. Increased organic 551 carbon content in the sediment has been shown to favour elevated meiofaunal abundance (Ingels 552 et al. 2009; Morse \& Beazley 2008). Sediment kurtosis is a measure of the particle size distribution, 553 and high values of kurtosis indicate that there are outliers in the distribution (heavy-tailed relative 554 to normal distribution), and could therefore be interpreted as a measure of habitat heterogeneity. 555 Similar proxies of sediment heterogeneity have been shown to influence meiofaunal abundance 556 (Netto et al. 2005), because habitat heterogeneity increases the partitioning of food resources 557 (Levin et al. 2001; Whitlatch 1981). 
Meiofaunal diversity was higher in the surface than subsurface sediment layer in both 559 regions. Similarly, Vanaverbeke et al. (1997) and Danovaro et al. (2002) found diversity was 560 typically highest in surface sediment and decreased in deeper sediments, where nematodes become 561 the dominant taxon. In the Hikurangi Margin, diversity in surface sediments was negatively 562 influenced by particle size diversity, mean particle size, and fishing. Negative relationship between 563 these variables and diversity may be an indication of indirect effect of trawling, as noted earlier. 564 The diversity of subsurface meiofauna was not correlated with trawling intensity, but was greater 565 in seafloor depressions than on flat or elevated ground. As mentioned earlier, seafloor depressions 566 may increase meiofauna settlement and deposition of organic matter due to reduced water flow, 567 and increased food availability may enhance diversity (Lambshead et al. 2000). The different 568 patterns observed between surface and subsurface sediment layers in the Hikurangi Margin may 569 reflect the greater exposure of surface communities to the direct and indirect effects of trawling. 570 In the Bay of Plenty surface sediment, surface chlorophyll concentration was positively correlated 571 to diversity, while water depth was negatively correlated to diversity. Surface chlorophyll 572 concentrations provide an indication of the flux of organic matter and phytodetritus to the sea floor, 573 and diversity can increase with an increase in organic flux (Lambshead et al. 2000). A decrease in 574 diversity with increased water depth is possibly related to decreased food availability with depth 575 (Vanaverbeke et al. 1997). In the Bay of Plenty subsurface sediment, kurtosis and sediment organic 576 carbon content were positively correlated to diversity. As described above, these findings are 577 consistent with increased habitat heterogeneity increasing the partitioning of food resources (Levin 578 et al. 2001; Whitlatch 1981), and increased organic carbon content in the sediment has been shown 579 to increase diversity (Lambshead et al. 2000). Thus, in the Bay of Plenty, meiofaunal diversity in 580 both surface and subsurface sediments were positively linked with proxies of food availability. It 581 remains unclear why a positive correlation between kurtosis and diversity was only found in 582 subsurface sediments. in both Hikurangi Margin and Bay of Plenty. Nauplii, copepods and kinorhynchs were the highest contributors to community dissimilarity between sediment depths for both regions, where the abundance of these taxa was higher in the surface than in the subsurface sediment. Nauplii and copepods are generally the second most abundant taxa after nematodes in the sediment (Danovaro 588 et al. 2002; Vanaverbeke et al. 1997). Typically, copepods and kinorhynchs occupy the well 
589 oxygenated sediment layer and are more sensitive to low oxygen concentrations than nematodes

590 (Grego et al. 2014; Vidakovic 1984), which may be the reason for their higher abundance in the 591 surface than subsurface sediment. The higher abundance of kinorhynchs may also be related to 592 higher food availability in surface sediments, since kinorhynch abundance has a positive 593 relationship with food availability (Shimanaga et al. 2000). In the Hikurangi Margin region, profile 594 curvature was most highly correlated with meiofaunal community structure in the surface 595 sediment, whilst curvature and phaeopigment were most correlated with community structure in 596 the subsurface sediment. As already noted, seafloor depressions tend to accumulate organic matter 597 and increased meiofaunal settlement from the water flow than elevated slope, and thus influence 598 community structure. The greater importance of phaeopigment for the subsurface community 599 compared to surface community may be due to the generally low food availability in subsurface 600 sediment layers, where limited shifts may have relatively strong effects on communities (Giere 601 2009). In the Bay of Plenty, surface chlorophyll concentration was correlated most to community 602 structure in the surface sediment, while kurtosis (a measure of habitat heterogeneity) was 603 correlated most to community structure in the subsurface sediment. These results largely reflect 604 similar patterns observed for abundance and diversity in the region.

\section{Relative vulnerability of meiofauna communities to anthropogenic disturbance}

Clear differences in meiofaunal community attributes between the two study regions imply potential regional differences in vulnerability to disturbance caused by bottom trawling, and other physical disturbances that may impact upon the seafloor in the future, such as seabed mining. Bottom trawling have been associated with sediment physical characteristics modification, reducing the availability of food within the sediment and altering habitat characteristics (Martín et al. 2014; Pusceddu et al. 2014). These impacts have been linked with changes in meiofauna abundance and diversity, although not necessarily declines in these community measures (Hinz et al. 2008; Pusceddu et al. 2014). However, short-term microcosm experiment on the effect of disturbance on deep-sea nematode colonisation on enriched and unenriched sediments showed that nematode abundance and diversity were significantly higher in the enriched sediment, suggesting that the presence of food can enhances meiofaunal recolonization, and resilience to disturbance (Gallucci et al. 2008). Thus, meiofauna communities in the Hikurangi Margin, which experience higher surface water productivity and related food availability in the sediment, could be less 
619 vulnerable to the effects of disturbance (from bottom trawling or seabed mining) than those in the

620 lower food availability sediments of the Bay of Plenty (Leduc et al. in press).

621 Within regions, abundance was the only community attribute that differed significantly 622 among habitats. The higher abundance at canyon habitats implies that the vulnerability of canyon 623 communities to anthropogenic disturbance may be different from that of other deep-sea 624 communities. Canyon communities differed from seamount and slope communities due to 625 differences in the abundance of a number of shared taxa, but the former communities also 626 supported slightly more rare taxa than slope and seamount communities. The presence of rare taxa 627 can make a community more susceptible to disturbance when they occur at low densities, as it 628 reduces the chances for successful recolonization, making them potentially vulnerable to localised 629 extinction events. Canyon communities might also be more vulnerable to bottom trawling than 630 other communities because of the generally steep topography of canyon habitats, which makes 631 them prone to slope instability and turbidity flows following trawling events (Puig et al. 2012). 632 This instability can have direct negative impacts on canyon meiofauna, since increased turbidity 633 and sedimentation rates may cause sudden burial of infauna, and slope instability can removed 634 organic-rich sediment down-slope to deeper parts of the canyon (Puig et al. 2012; Pusceddu et al. 635 2014). Conversely, this organic matter enrichment from the upper canyon might favour meiofauna 636 at deeper locations. Nevertheless, other physical characteristics of canyons, such as the presence 637 of hard substrates and complex topography may protect areas of soft sediment from physical 638 disturbance, providing a source for faunal recolonization to disturbed areas of the canyon (Puig et 639 al. 2012). 641 showed that community abundance, diversity and community structure in seeps were different 642 compared with canyon, slope and seamount habitats. Meiofauna seep communities maybe more 643 vulnerable to disturbance because seep habitats: (1) have complex geological morphology and 644 biogenic structures that increase the microhabitat heterogeneity, which in turns supports a distinct 645 and diverse meiofaunal community that includes temporary meiofauna (such as priapulid larvae 646 that were observed only at the seep habitat in this study); (2) the relatively small and localized seep 647 microhabitats and the sometimes large distances between habitat patches (Greinert et al. 2010), 648 can reduce chances for successful recolonization following anthropogenic disturbance and make 
649 seep communities potentially vulnerable to localised extinction events; and (3) potential 650 modification of fluid flow patterns resulting from future large-scale extraction of methane hydrates 651 might affect the persistence or structure of seep communities (Baco et al. 2010; Bowden et al. 652 2013). Seep habitat and megafauna in the Hikurangi Margin are known to have already been 653 subjected to fishing impacts, and could be subjected to drilling for hydrates in the future (Baco et 654 al. 2010; Bowden et al. 2013).

655

656

657

658

659

660

661

662

663

664

665

666

667

668

669

670

671

672

673

674

675

676

677

678

679

Clear differences in meiofaunal communities between surface and subsurface sediment layers also imply a relative vulnerability to disturbance, such as from bottom trawling or seabed mining. Bottom trawling can cause widespread damage to sediment column by increased sediment resuspension and deposition, sediment particle size alteration and reduced food availability within the sediment, including changes in oxygen penetration depths (Martín et al. 2014). These habitat modifications can have an impact on infauna (Pusceddu et al. 2014; Schratzberger et al. 2009), and likely to be greater for fauna inhabiting surface of the sediment. Copepods and kinorhynchs, for example, are generally more prevalent in surface than subsurface sediment (Grego et al. 2014; Shimanaga et al. 2000), making them vulnerable to disturbance that may only affect the sediment surface. In contrast, nematodes can penetrate deeper into the sediment (up to $50 \mathrm{~cm}$ depending on sediment types) as they are more tolerant of low oxygen concentrations (Grego et al. 2014; Moens et al. 2014) and may therefore avoid some of the impacts. However, previous studies also found large differences in sediment compaction between untrawled and trawled areas, where surface sediment at trawled areas are much denser, which may affect the nematodes abilities to penetrate deeper in the sediment column (Martín et al. 2014; Pusceddu et al. 2014). Meiofauna may also be resuspended by physical disturbances, instead of being killed directly because of their smaller sizes, and can quickly recolonize the sediment column. Copepods can rapidly recolonise sediments via active dispersal in the water column, while nematodes can only recolonise sediment directly from adjacent undisturbed sediment or through suspended sediment transport (Schratzberger et al. 2004). Nematodes can withstand disturbance and recover faster than other sediment inhabiting meiofaunal groups subjected to disturbance, probably due to their high abundance and short generation time (Schratzberger et al. 2002; Sherman \& Coull 1980), and may thus dominate surface sediment meiofauna communities following trawling (Schratzberger et al. 2000). Deepsea mining when it occurs could also cause disruption to the seafloor, but this is likely to result in surface and subsurface sediment meiofauna being equally vulnerable to disturbance. While some 
680 deep-sea minerals are found predominantly on the seafloor surface (e.g. phosphate and manganese 681 nodules), present designs for mining tools are expected to disturb at least the upper 5-10 cm layer 682 of soft sediment, and impact the meiofauna to this depth (Miljutin et al. 2011). Similarly, impacts 683 from certain types of trawling will penetrate well into the subsurface layer (Martín et al. 2014). 684 Thus, it is clear that meiofaunal communities are vulnerable to disturbance, and living deeper in 685 the sediment does not necessarily offer protection.

686

687

688

689

690

691

692

693

694

695

696

697

698

699

700

701

702

703

704

705

706

707

708

709

710

711

712

713

\section{Acknowledgments}

This study was part of NIWA's research project 'Impact of resource use on vulnerable deep-sea communities' (CO1X0906). We thank the scientific personnel of voyages TAN0616, TAN1004, and TAN1206, and the officers and crew of RV Tangaroa. We are also grateful to Lisa Northcote and Karen Thompson (NIWA) for sediment analyses, and Andy McKenzie (NIWA) for help in R software.

\section{References}

Anderson MJ, Gorley RN, and Clarke KR. 2008. PERMANOVA+for PRIMER: guide to software and statistical methods. Plymouth: PRIMER-E.

Baco AR, Rowden AA, Levin LA, Smith CR, and Bowden DA. 2010. Initial characterization of cold seep faunal communities on the New Zealand Hikurangi margin. Marine Geology 272:251-259. 10.1016/j.margeo.2009.06.015

Baguley JG, Montagna PA, Hyde LJ, Kalke RD, and Rowe GT. 2006. Metazoan meiofauna abundance in relation to environmental variables in the northern Gulf of Mexico deep sea. Deep-Sea Research Part I-Oceanographic Research Papers 53:1344-1362. 10.1016/j.dsr.2006.05.012

Bashmachnikov I, Loureiro CM, and Martins A. 2013. Topographically induced circulation patterns and mixing over Condor seamount. Deep Sea Research Part II: Topical Studies in Oceanography 98, Part A:38-51. http://dx.doi.org/10.1016/j.dsr2.2013.09.014

Benn AR, Weaver PP, Billet DSM, van den Hove S, Murdock AP, Doneghan GB, and Le Bas T. 2010. Human activities on the deep seafloor in the North East Atlantic: an assessment of spatial extent. Plos One 5:e12730. 10.1371/journal.pone.0012730

Bianchelli S, Gambi C, Pusceddu A, and Danovaro R. 2008. Trophic conditions and meiofaunal assemblages in the Bari Canyon and the adjacent open slope (Adriatic Sea). Chemistry and Ecology 24:101-109. 10.1080/02757540801963386

Bianchelli S, Gambi C, Zeppilli D, and Danovaro R. 2010. Metazoan meiofauna in deep-sea canyons and adjacent open slopes: a large-scale comparison with focus on the rare taxa. 
714

715

716

717

718

719

720

721

722

723

724

725

726

727

728

729

730

731

732

733

734

735

736

737

738

739

740

741

742

743

744

745

746

747

748

749

750

751

752

753

754

755

756

757

758

759

Deep-Sea Research Part I-Oceanographic Research Papers 57:420-433. 10.1016/j.dsr.2009.12.001

Black J, and Wood R. 2014. Analysis of New Zealand's trawl grounds for key middle depths and deepwater tier 1 fishes. New Zealand Aquatic Environment and Biodiversity Report $122: 35 \mathrm{pp}$.

Boeckner MJ, Sharma J, and Proctor HC. 2009. Revisiting the meiofauna paradox: dispersal and colonization of nematodes and other meiofaunal organisms in low- and high-energy environments. Hydrobiologia 624:91-106. 10.1007/s10750-008-9669-5

Bongiorni L, Ravara A, Parretti P, Santos RS, Rodrigues CF, Amaro T, and Cunha MR. 2013. Organic matter composition and macrofaunal diversity in sediments of the Condor Seamount (Azores, NE Atlantic). Deep Sea Research Part II: Topical Studies in Oceanography 98, Part A:75-86. http://dx.doi.org/10.1016/j.dsr2.2013.08.006

Boschen RE, Rowden AA, Clark MR, and Gardner JPA. 2013. Mining of deep-sea seafloor massive sulfides: A review of the deposits, their benthic communities, impacts from mining, regulatory frameworks and management strategies. Ocean \& Coastal Management 84:54-67. 10.1016/j.ocecoaman.2013.07.005

Bowden DA, Rowden AA, Leduc D, Beaumont J, and Clark MR. 2016. Deep-sea seabed habitats: Do they support distinct mega-epifaunal communities that have different vulnerabilities to anthropogenic disturbance? Deep Sea Research Part I: Oceanographic Research Papers 107:31-47. http://dx.doi.org/10.1016/j.dsr.2015.10.011

Bowden DA, Rowden AA, Thurber AR, Baco AR, Levin LA, and Smith CR. 2013. Cold seep epifaunal communities on the Hikurangi Margin, New Zealand: composition, succession, and vulnerability to human activities. Plos One 8:20. 10.1371/journal.pone.0076869

Butman CA. 1987. Larval settlement of soft-sediment invertebrates - the spatial scales of pattern explained by active habitat selection and the emerging role of hydrodynamical processes. Oceanography and Marine Biology: an Annual Review 25:113-165.

Canals M, Puig P, de Madron XD, Heussner S, Palanques A, and Fabres J. 2006. Flushing submarine canyons. Nature 444:354-357. 10.1038/nature05271

Clark MR. 1995. Experience with the management of orange roughy (Hoplostethus atlanticus) in New Zealand, and the effects of commercial fishing on stocks over the period 1980-1993. In: AG H, ed. Deep-water fisheries of the North Atlantic oceanic slope. Netherlands: Kluwer, 251-266.

Clark MR, and O'Driscoll R. 2003. Deepwater fisheries and aspects of their impact on seamount habitat in New Zealand. Journal of Northwest Atlantic Fishery Science 31:441-458.

Clark MR, Rowden AA, Schlacher T, Williams A, Consalvey M, Stocks KI, Rogers AD, O'Hara TD, White M, Shank TM, and Hall-Spencer JM. 2010. The Ecology of Seamounts: Structure, Function, and Human Impacts. Annual Review of Marine Science. Palo Alto: Annual Reviews, 253-278.

Clarke KR, and Gorley RN. 2006. PRIMER v6: User Manual/Tutorial. . Plymouth: PRIMER-E Ltd.

Danovaro R, Bianchelli S, Gambi C, and Zeppilli D. 2009. $\alpha-, \beta-, \gamma-, \delta$ - and $\varepsilon$ - diversity of deepsea nematodes in canyons and open slopes of Northeast Atlantic and Mediterranean margins. Marine Ecology Progress Series 396:197-209. 10.3354/MEPS08269

Danovaro R, Gambi C, and Della Croce N. 2002. Meiofauna hotspot in the Atacama Trench, eastern South Pacific Ocean. Deep Sea Research Part I: Oceanographic Research Papers 49:843-857. http://dx.doi.org/10.1016/S0967-0637(01)00084-X

PeerJ reviewing PDF | (2016:03:9706:1:1:NEW 19 May 2016) 
760

761

762

763

764

765

766

767

768

769

770

771

772

773

774

775

776

777

778

779

780

781

782

783

784

785

786

787

788

789

790

791

792

793

794

795

796

797

798

799

800

801

802

803

804

805 de Stigter HC, Boer W, de Jesus Mendes PA, Jesus CC, Thomsen L, van den Bergh GD, and van Weering TCE. 2007. Recent sediment transport and deposition in the Nazare Canyon, Portuguese continental margin. Marine Geology 246:144-164. http://dx.doi.org/10.1016/j.margeo.2007.04.011

Etter RJ, and Grassle JF. 1992. Patterns of species-diversity in the deep-sea as a function of sediment particle-size diversity. Nature 360:576-578. 10.1038/360576a0

Fleeger JW, Yund PO, and Sun B. 1995. Active and passive processes associated with initial settlement and postsettlement dispersal of suspended meiobenthic copepods. Journal of Marine Research 53:609-645. 10.1357/0022240953213070

Gallucci F, Moens T, Vanreusel A, and Fonseca G. 2008. Active colonisation of disturbed sediments by deep-sea nematodes: evidence for the patch mosaic model. Marine Ecology Progress Series 367:173-183. 10.3354/meps07537

García R, van Oevelen D, Soetaert K, Thomsen L, De Stigter HC, and Epping E. 2008. Deposition rates, mixing intensity and organic content in two contrasting submarine canyons. Progress in Oceanography 76:192-215. http://dx.doi.org/10.1016/j.pocean.2008.01.001

Giere O. 2009. Meiobenthology. The microscopic motile fauna of aquatic sediments. Berlin: Springer-Verlag.

Grego M, Riedel B, Stachowitsch M, and De Troch M. 2014. Meiofauna winners and losers of coastal hypoxia: case study harpacticoid copepods. Biogeosciences 11:281-292. $10.5194 / \mathrm{bg}-11-281-2014$

Greinert J, Lewis KB, Bialas J, Pecher IA, Rowden A, Bowden DA, De Batist M, and Linke P. 2010. Methane seepage along the Hikurangi Margin, New Zealand: overview of studies in 2006 and 2007 and new evidence from visual, bathymetric and hydroacoustic investigations. Marine Geology 272:6-25. 10.1016/j.margeo.2010.01.017

Grove SL, Probert PK, Berkenbusch K, and Nodder SD. 2006. Distribution of bathyal meiofauna in the region of the Subtropical Front, Chatham Rise, south-west Pacific. Journal of Experimental Marine Biology and Ecology 330:342-355. 10.1016/j.jembe.2005.12.038

Hansson M, Lindegarth M, Valentinsson D, and Ulmestrand M. 2000. Effects of shrimp-trawling on abundance of benthic macrofauna in Gullmarsfjorden, Sweden. Marine Ecology Progress Series 198:191-201. 10.3354/meps198191

Hein JR, Mizell K, Koschinsky A, and Conrad TA. 2013. Deep-ocean mineral deposits as a source of critical metals for high- and green-technology applications: comparison with land-based resources. Ore Geology Reviews 51:1-14. 10.1016/j.oregeorev.2012.12.001

Heip C, Vincx M, and Vranken G. 1985. The ecology of marine nematodes. Oceanography and Marine Biology: an Annual Review 23:399-489.

Higgins RP, and Thiel H. 1988. Introduction to the Study of Meiofauna. Washigton DC.: Smithsonian Institution Press.

Hinz H, Hiddink JG, Forde J, and Kaiser MJ. 2008. Large-scale responses of nematode communities to chronic otter-trawl disturbance. Canadian Journal of Fisheries and Aquatic Sciences 65:723-732. 10.1139/f08-002

Hinz H, Prieto V, and Kaiser MJ. 2009. Trawl disturbance on benthic communities: chronic effects and experimental predictions. Ecological Applications 19:761-773. 10.1890/08-0351.1

Ingels J, Billett DSM, Kiriakoulakis K, Wolff GA, and Vanreusel A. 2011a. Structural and functional diversity of Nematoda in relation with environmental variables in the Setúbal and Cascais canyons, Western Iberian Margin. Deep Sea Research Part II: Topical Studies in Oceanography 58:2354-2368. 10.1016/j.dsr2.2011.04.002 
806

807

808

809

810

811

812

813

814

815

816

817

818

819

820

821

822

823

824

825

826

827

828

829

830

831

832

833

834

835

836

837

838

839

840

841

842

843

844

845

846

847

848

849

850

851
Ingels J, Kiriakoulakis K, Wolff GA, and Vanreusel A. 2009. Nematode diversity and its relation to the quantity and quality of sedimentary organic matter in the deep Nazare Canyon, Western Iberian Margin. Deep Sea Research Part I: Oceanographic Research Papers 56:1521-1539. http://dx.doi.org/10.1016/j.dsr.2009.04.010

Ingels J, Tchesunov AV, and Vanreusel A. 2011b. Meiofauna in the Gollum Channels and the Whittard Canyon, Celtic Margin-how local environmental conditions shape nematode sructure and function. Plos One 6:1-15. 10.1371/journal.pone.0020094

Ingels J, and Vanreusel A. 2013. The importance of different spatial scales in determining structure and function of deep-sea infauna communities. Biogeosciences Discuss 10:195-232.

Judd A, Jukes V, and Leddra M. 2002. MAGIC: A GIS database of marine gas seeps and seep indicators. Geologiya I Geofizika 43:599-604.

Lambshead PJD, Brown CJ, Ferrero TJ, Mitchell NJ, Smith CR, Hawkins LE, and Tietjen J. 2002. Latitudinal diversity patterns of deep-sea marine nematodes and organic fluxes: a test from the central equatorial Pacific. Marine Ecology Progress Series 236:129-135. 10.3354/meps236129

Lambshead PJD, Tietjen J, Ferrero T, and Jensen P. 2000. Latitudinal diversity gradients in the deep sea with special reference to North Atlantic nematodes. Marine Ecology Progress Series 194:159-167. 10.3354/meps194159

Lampadariou N, Hatziyanni E, and Tselepides A. 2005. Meiofaunal community structure in Thermaikos Gulf: response to intense trawling pressure. Continental Shelf Research 25:2554-2569. http://dx.doi.org/10.1016/j.csr.2005.08.016

Lampadariou N, Kalogeropoulou V, Sevastou K, Keklikoglou K, and Sarrazin J. 2013. Influence of chemosynthetic ecosystems on nematode community structure and biomass in the deep eastern Mediterranean Sea. Biogeosciences 10:5381-5398. 10.5194/bg-10-5381-2013

Lampadariou N, and Tselepides A. 2006. Spatial variability of meiofaunal communities at areas of contrasting depth and productivity in the Aegean Sea (NE Mediterranean). Progress in Oceanography 69:19-36. http://dx.doi.org/10.1016/j.pocean.2006.02.013

Leduc D, and Pilditch CA. 2013. Effect of a physical disturbance event on deep-sea nematode community structure and ecosystem function. Journal of Experimental Marine Biology and Ecology 440:35-41. http://dx.doi.org/10.1016/j.jembe.2012.11.015

Leduc D, Rowden AA, Clark MR, Bowden DA, and Thurber AR. in press. Limited differences among habitats in deep-sea macro-infaunal communities off New Zealand: implications for their vulnerability to anthropogenic disturbance.

Leduc D, Rowden AA, Nodder SD, Berkenbusch K, Probert PK, and Hadfield MG. 2014. Unusually high food availability in Kaikoura Canyon linked to distinct deep-sea nematode community. Deep Sea Research II 104:310-318.

Leduc D, Rowden AA, Probert PK, Pilditch CA, Nodder SD, Vanreusel A, Duineveld GCA, and Witbaard R. 2012. Further evidence for the effect of particle-size diversity on deep-sea benthic biodiversity. Deep-Sea Research Part I-Oceanographic Research Papers 63:164169. 10.1016/j.dsr.2011.10.009

Legendre P. 1993. Spatial autocorrelation - Trouble or new paradigm. Ecology 74:1659-1673. $10.2307 / 1939924$

Legendre P, and Troussellier M. 1988. Aquatic Heterotrophic bacteria - Modelling in the presence of spatial auto-correlation. Limnology and Oceanography 33:1055-1067.

Levin LA. 2005. Ecology of Cold Seep Sediments. Oceanography and Marine Biology: CRC Press, 1-46. 
852

853

854

855

856

857

858

859

860

861

862

863

864

865

866

867

868

869

870

871

872

873

874

875

876

877

878

879

880

881

882

883

884

885

886

887

888

889

890

891

892

893

894

895

896

897

Levin LA, and Dibacco C. 1995. Influence of sediment transport on short-term recolonization by seamount infauna. Marine Ecology Progress Series 123:163-175. 10.3354/meps 123163

Levin LA, Etter RJ, Rex MA, Gooday AJ, Smith CR, Pineda J, Stuart CT, Hessler RR, and Pawson D. 2001. Environmental influences on regional deep-sea species diversity. Annual Review of Ecology and Systematics 32:51-93. 10.1146/annurev.ecolsys.32.081501.114002

Levin LA, and Mendoza GF. 2007. Community structure and nutrition of deep methane-seep macrobenthos from the North Pacific (Aleutian) Margin and the Gulf of Mexico (Florida Escarpment). Marine Ecology-an Evolutionary Perspective 28:131-151. 10.1111/j.14390485.2006.00131.x

Levin LA, Mendoza GF, Konotchick T, and Lee R. 2009. Macrobenthos community structure and trophic relationships within active and inactive Pacific hydrothermal sediments. Deep Sea Research Part II: Topical Studies in Oceanography 56:1632-1648. http://dx.doi.org/10.1016/j.dsr2.2009.05.010

Levin LA, and Sibuet M. 2012. Understanding continental margin biodiversity: a new imperative. Annual Review of Marine Science 4:79-+. 10.1146/annurev-marine-120709-142714

Levin LA, Sibuet M, Gooday AJ, Smith CR, and Vanreusel A. 2010. The roles of habitat heterogeneity in generating and maintaining biodiversity on continental margins: an introduction. Marine Ecology 31:1-5. 10.1111/j.1439-0485.2009.00358.x

Liu XS, Cheung SG, and Shin PKS. 2009. Meiofauna with special reference to nematodes in trawling ground of subtropical Hong Kong. Marine Pollution Bulletin 58:607-615. 10.1016/j.marpolbul.2009.01.002

Liu XS, Xu WZ, Cheung SG, and Shin PKS. 2011. Response of meiofaunal community with special reference to nematodes upon deployment of artificial reefs and cessation of bottom trawling in subtropical waters, Hong Kong. Marine Pollution Bulletin 63:376-384. http://dx.doi.org/10.1016/j.marpolbul.2010.11.019

Martín J, Puig P, Masqué P, Palanques A, and Sánchez-Gómez A. 2014. Impact of bottom trawling on deep-sea sediment properties along the flanks of a submarine canyon. Plos One 9:e104536. 10.1371/journal.pone.0104536

McClain CR, and Barry JP. 2010. Habitat heterogeneity, disturbance, and productivity work in concert to regulate biodiversity in deep submarine canyons. Ecology 91:964-976. 10.1890/09-0087.1

Miljutin DM, Miljutina MA, Arbizu PM, and Galeron J. 2011. Deep-sea nematode assemblage has not recovered 26 years after experimental mining of polymetallic nodules (ClarionClipperton Fracture Zone, Tropical Eastern Pacific). Deep-Sea Research Part IOceanographic Research Papers 58:885-897. 10.1016/j.dsr.2011.06.003

Moens T, Braeckman U, Derycke S, Fonseca G, Gallucci F, Gingold R, Guilini K, Ingels J, Leduc D, Vanaverbeke J, Colen CV, Vanreusel A, and Vincx M. 2014. Ecology of free-living marine nematodes. In: Schmidt-Rhaesa A, ed. Volume 2 Nematoda. Berlin, Boston: De Gruyter, 109-152.

Morse JW, and Beazley MJ. 2008. Organic matter in deepwater sediments of the Northern Gulf of Mexico and its relationship to the distribution of benthic organisms. Deep Sea Research Part II: Topical Studies in Oceanography 55:2563-2571. http://dx.doi.org/10.1016/j.dsr2.2008.07.004

Mountjoy JJ, Barnes PM, and Pettinga JR. 2009. Morphostructure and evolution of submarine canyons across an active margin: Cook Strait sector of the Hikurangi Margin, New Zealand. Marine Geology 260:45-68. http://dx.doi.org/10.1016/j.margeo.2009.01.006 
898

899

900

901

902

903

904

905

906

907

908

909

910

911

912

913

914

915

916

917

918

919

920

921

922

923

924

925

926

927

928

929

930

931

932

933

934

935

936

937

938

939

940

941

942

Neira C, Sellanes J, Levin LA, and Arntz WE. 2001. Meiofaunal distributions on the Peru margin: relationship to oxygen and organic matter availability. Deep-Sea Research Part IOceanographic Research Papers 48:2453-2472. 10.1016/s0967-0637(01)00018-8

Netto SA, Gallucci F, and Fonseca GFC. 2005. Meiofauna communities of continental slope and deep-sea sites off SE Brazil. Deep Sea Research Part I: Oceanographic Research Papers 52:845-859. http://dx.doi.org/10.1016/j.dsr.2004.11.009

Nodder SD, Duineveld GCA, Pilditch CA, Sutton PJ, Probert PK, Lavaleye MSS, Witbaard R, Chang FH, Hall JA, and Richardson KM. 2007. Focusing of phytodetritus deposition beneath a deep-ocean front, Chatham Rise, New Zealand. Limnology and Oceanography 52:299-314.

Nodder SD, Pallentin A, Mackay K, and Bowden DA. 2013. Seafloor morphology and substrate characterisation on Chatham Rise. NIWA Client Report prepared for Chatham Rock Phosphate Ltd:38p.

Nodder SD, Pilditch CA, Probert PK, and Hall JA. 2003. Variability in benthic biomass and activity beneath the Subtropical Front, Chatham Rise, SW Pacific Ocean. Deep Sea Research Part I: Oceanographic Research Papers 50:959-985. 10.1016/s09670637(03)00094-3

Pape E, Nara Bezerra T, Vanneste H, Heeschen K, Moodley L, Leroux F, van Breugel P, and Vanreusel A. 2011. Community structure and feeding preference of nematodes associated with methane seepage at the Darwin mud volcano (Gulf of Cádiz). Marine Ecology Progress Series 438:71-83. 10.3354/meps09278

Pecher IA, and Henrys SA. 2003. Potential gas reserves in gas hydrate sweet spots on the Hikurangi Margin, New Zealand. Institute of Geological and Nuclear Sciences, 2003/23.

Pitcher T, Morato T, Hart PJB, Clark MR, Haggan N, and Santos RS. 2007. Seamounts: Ecology, Fisheries and Conservation. . Oxford UK: Blackwell

Pitcher TJ, Clark MR, Morato T, and Watson R. 2010. Seamount fisheries: do they have a future? . Oceanography 23:134-144.

Pranovi F, Raicevich S, Franceschini G, Farrace MG, and Giovanardi O. 2000. Rapido trawling in the northern Adriatic Sea: effects on benthic communities in an experimental area. Ices Journal of Marine Science 57:517-524. 10.1006/jmsc.2000.0708

Puig P, Canals M, Company JB, Martin J, Amblas D, Lastras G, Palanques A, and Calafat AM. 2012. Ploughing the deep sea floor. Nature 489:286-+. 10.1038/nature 11410

Pusceddu A, Bianchelli S, Martin J, Puig P, Palanques A, Masque P, and Danovaro R. 2014. Chronic and intensive bottom trawling impairs deep-sea biodiversity and ecosystem functioning. Proceedings of the National Academy of Sciences of the United States of America 111:8861-8866. 10.1073/pnas.1405454111

Pusceddu A, Gambi C, Zeppilli D, Bianchelli S, and Danovaro R. 2009. Organic matter composition, metazoan meiofauna and nematode biodiversity in Mediterranean deep-sea sediments. Deep-Sea Research Part Ii-Topical Studies in Oceanography 56:755-762. 10.1016/j.dsr2.2008.10.012

Ramirez-Llodra E, Trannum HC, Evenset A, Levin LA, Andersson M, Finne TE, Hilario A, Flem B, Christensen G, Schaanning M, and Vanreusel A. 2015. Submarine and deep-sea mine tailing placements: A review of current practices, environmental issues, natural analogs and knowledge gaps in Norway and internationally. Marine Pollution Bulletin 97:13-35. http://dx.doi.org/10.1016/j.marpolbul.2015.05.062 
943

944

945

946

947

948

949

950

951

952

953

954

955

956

957

958

959

960

961

962

963

964

965

966

967

968

969

970

971

972

973

974

975

976

977

978

979

980

981

982

983

984

985

986

987

988

Ramirez-Llodra E, Tyler PA, Baker MC, Bergstad OA, Clark MR, Escobar E, Levin LA, Menot L, Rowden AA, Smith CR, and Van Dover CL. 2011. Man and the Last Great Wilderness: Human Impact on the Deep Sea. Plos One 6:e22588. 10.1371/journal.pone.0022588

Rex MA, and Etter RJ. 2010. Deep - Sea Biodiversity: Pattern and Scale. USA: Harvard University Press.

Robinson CA, Bernhard JM, Levin LA, Mendoza GF, and Blanks JK. 2004. Surficial hydrocarbon seep infauna from the Blake Ridge (Atlantic Ocean, $2150 \mathrm{~m}$ ) and the Gulf of Mexico (6902240 m). Marine Ecology 25:313-336. 10.1111/j.1439-0485.2004.00034.x

Romano C, Coenjaerts J, Flexas MM, Zuniga D, Vanreusel A, Company JB, and Martin D. 2013. Spatial and temporal variability of meiobenthic density in the Blanes submarine canyon (NW Mediterranean). Progress in Oceanography 118:144-158. 10.1016/j.pocean.2013.07.026

Ruff SE, Arnds J, Knittel K, Amann R, Wegener G, Ramette A, and Boetius A. 2013. Microbial communities of deep-sea methane seeps at Hikurangi Continental Margin (New Zealand). Plos One 8:e72627. 10.1371/journal.pone.0072627

Schmidt C, and Martínez Arbizu P. 2015. Unexpectedly higher metazoan meiofauna abundances in the Kuril-Kamchatka Trench compared to the adjacent abyssal plains. Deep Sea Research Part II: Topical Studies in Oceanography 111:60-75. http://dx.doi.org/10.1016/j.dsr2.2014.08.019

Schratzberger M, Dinmore TA, and Jennings S. 2002. Impacts of trawling on the diversity, biomass and structure of meiofauna assemblages. Marine Biology 140:83-93. $10.1007 / \mathrm{s} 002270100688$

Schratzberger M, and Jennings S. 2002. Impacts of chronic trawling disturbance on meiofaunal communities. Marine Biology 141:991-1000. 10.1007/s00227-002-0895-5

Schratzberger M, Lampadariou N, Somerfield P, Vandepitte L, and Vanden Berghe E. 2009. The impact of seabed disturbance on nematode communities: linking field and laboratory observations. Marine Biology 156:709-724. 10.1007/s00227-008-1122-9

Schratzberger M, Rees HL, and Boyd SE. 2000. Effects of simulated deposition of dredged material on structure of nematode assemblages - the role of burial. Marine Biology 136:519-530. 10.1007/s002270050712

Schratzberger M, Whomersley P, Warr K, Bolam SG, and Rees HL. 2004. Colonisation of various types of sediment by estuarine nematodes via lateral infaunal migration: a laboratory study. Marine Biology 145:69-78. 10.1007/s00227-004-1302-1

Sherman KM, and Coull BC. 1980. The response of meiofauna to sediment disturbance. Journal of Experimental Marine Biology and Ecology 46:59-71. http://dx.doi.org/10.1016/00220981(80)90091-X

Shimanaga M, Kitazato H, and Shirayama Y. 2000. Seasonal patterns of vertical distribution between meiofaunal groups in relation to phytodetritus deposition in the bathyal Sagami Bay, central Japan. Journal of Oceanography 56:379-387. 10.1023/a:1011120204419

Shirayama Y, and Ohta S. 1990. Meiofauna in a cold-seep community off Hatsushima Central Japan. Journal of the Oceanographical Society of Japan 46:118-124. 10.1007/bf02123438

Soetaert K, and Heip C. 1995. Nematode assemblages of deep-sea and shelf break sites in the North-Atlantic and Mediterranean Sea. Marine Ecology Progress Series 125:171-183. 10.3354/meps 125171

Soetaert K, Vanaverbeke J, Heip C, Herman PMJ, Middelburg JJ, Sandee A, and Duineveld G. 1997. Nematode distribution in ocean margin sediments of the Goban Spur (northeast 
Atlantic) in relation to sediment geochemistry. Deep-Sea Research Part I-Oceanographic Research Papers 44:1671-1683. 10.1016/s0967-0637(97)00043-5

Soltwedel T. 2000. Metazoan meiobenthos along continental margins: a review. Progress in Oceanography 46:59-84. 10.1016/s0079-6611(00)00030-6

Soltwedel T, Hasemann C, Queric NV, and von Juterzenka K. 2005. Gradients in activity and biomass of the small benthic biota along a channel system in the deep Western Greenland Sea. Deep-Sea Research Part I-Oceanographic Research Papers 52:815-835. 10.1016/j.dsr.2004.11.011

Somerfield PJ, and Clarke KR. 1995. Taxonomic levels in marine community studies, Revisited. Marine Ecology Progress Series 127:113-119. 10.3354/meps127113

Somerfield PJ, and Warwick RM. 1996. Meiofauna in marine pollution monitoring programmes: a laboratory manual. Lowestoft UK: Ministry of Agriculture, Fisheries and Food.

Sun B, and Fleeger JW. 1994. Field experiments on the colonization of meiofauna into sediment depressions. Marine Ecology Progress Series 110:167-175.

Van Dover CL. 2014. Impacts of anthropogenic disturbances at deep-sea hydrothermal vent ecosystems: A review. Marine Environmental Research 102:59-72. http://dx.doi.org/10.1016/j.marenvres.2014.03.008

Van Gaever S, Galeron J, Sibuet M, and Vanreusel A. 2009. Deep-sea habitat heterogeneity influence on meiofaunal communities in the Gulf of Guinea. Deep-Sea Research Part IiTopical Studies in Oceanography 56:2259-2269. 10.1016/j.dsr2.2009.04.008

Van Gaever S, Moodley L, de Beer D, and Vanreusel A. 2006. Meiobenthos at the Arctic Hakon Mosby Mud Volcano, with a parental-caring nematode thriving in sulphide-rich sediments. Marine Ecology Progress Series 321:143-155. 10.3354/meps321143

Vanaverbeke J, Soetaert K, Heip C, and Vanreusel A. 1997. The metazoan meiobenthos along the continental slope of the Goban Spur (NE Atlantic). Journal of Sea Research 38:93-107. 10.1016/s1385-1101(97)00038-5

Vanreusel A, Fonseca G, Danovaro R, da Silva MC, Esteves AM, Ferrero T, Gad G, Galtsova V, Gambi C, da Fonsêca Genevois V, Ingels J, Ingole B, Lampadariou N, Merckx B, Miljutin D, Miljutina M, Muthumbi A, Netto S, Portnova D, Radziejewska T, Raes M, Tchesunov A, Vanaverbeke J, Van Gaever S, Venekey V, Nara Bezerra T, Flint H, Copley J, Pape E, Zeppilli D, Arbizu Martinez P, and Galeron J. 2010. The contribution of deep-sea macrohabitat heterogeneity to global nematode diversity. Marine Ecology 31:6-20.

Vanreusel A, Vincx M, Schram D, and Vangansbeke D. 1995. On the vertical-distribution of the metazoan meiofauna in shelf break and upper slope habitats of the NE Atlantic. Internationale Revue Der Gesamten Hydrobiologie 80:313-326. 10.1002/iroh.19950800218

Vidakovic J. 1984. Meiofauna of silty sediments in the coastal area of the north adriatic with special reference to sampling methods. Heip, C, 67-72.

Weaver PPE, Wynn RB, Kenyon NH, and Evan J. 2000. Continental margin sedimentation, with special reference to the north-east Atlantic margin. Sedimentology 47:239-256. 10.1046/j.1365-3091.2000.0470s 1239.x

White M, Bashmachnikov I, Arístegui J, and Martins A. 2007. Physical process and seamount productivity. In: Pitcher T, Morato T, Hart PJB, Clark MR, Haggan N, and Santos RS, eds. Seamounts: Ecology, Fisheries and Conservation Oxford UK: Blackwell 65-84. 
1033

1034

1035

1036

1037

1038

1039

1040

1041

1042

1043

1044

1045

1046

1047

1048

1049

1050

1051

1052

1053

1054

1055

1056

1057

1058

1059

1060

1061

1062
Whitlatch RB. 1981. Animal-sediment relationships in intertidal marine benthic habitats: Some determinants of deposit-feeding species diversity. Journal of Experimental Marine Biology and Ecology 53:31-45. http://dx.doi.org/10.1016/0022-0981(81)90082-4

Whomersley P, Huxham M, Schratzberger M, and Bolam S. 2009. Differential response of meioand macrofauna to in situ burial. Journal of the Marine Biological Association of the United Kingdom 89:1091-1098. 10.1017/s0025315409000344

Wysoczanski R, and Clark M. 2012. Southern Kermadec Arc - Havre Trough geohabitats. In: Harris PT, and Baker EK, eds. Seafloor geomorphology as benthic habitat: GeoHab Atlas of seafloor geomorphic features and benthic habitats. Elsevier, London, UK: Elsevier Insights series, 900.

Zeppilli D, Bongiorni L, Cattaneo A, Danovaro R, and Santos RS. 2013. Meiofauna assemblages of the Condor Seamount (North-East Atlantic Ocean) and adjacent deep-sea sediments. Deep Sea Research Part II: Topical Studies in Oceanography 98, Part A:87-100. http://dx.doi.org/10.1016/j.dsr2.2013.08.009

Zeppilli D, Bongiorni L, Serrão Santos R, and Vanreusel A. 2014. Changes in nematode communities in different physiographic sites of the Condor Seamount (North-East Atlantic Ocean) and adjacent sediments. Plos One 9:e115601. 10.1371/journal.pone.0115601

Zeppilli D, Canals M, and Danovaro R. 2012. Pockmarks enhance deep-sea benthic biodiversity: a case study in the western Mediterranean Sea. Diversity and Distributions 18:832-846. 10.1111/j.1472-4642.2011.00859.x

Zeppilli D, Mea M, Corinaldesi C, and Danovaro R. 2011. Mud volcanoes in the Mediterranean Sea are hot spots of exclusive meiobenthic species. Progress in Oceanography 91:260272. http://dx.doi.org/10.1016/j.pocean.2011.01.001

Zeppilli D, Sarrazin J, Leduc D, Arbizu PM, Fontaneto D, Fontanier C, Gooday AJ, Kristensen RM, Ivanenko VN, Sorensen MV, Vanreusel A, Thebault J, Mea M, Allio N, Andro T, Arvigo A, Castrec J, Danielo M, Foulon V, Fumeron R, Hermabessiere L, Hulot V, James T, Langonne-Augen R, Le Bot T, Long M, Mahabror D, Morel Q, Pantalos M, Pouplard E, Raimondeau L, Rio-Cabello A, Seite S, Traisnel G, Urvoy K, Van der Stegen T, Weyand M, and Fernandes D. 2015. Is the meiofauna a good indicator for climate change and anthropogenic impacts? Marine Biodiversity 45:505-535. 10.1007/s12526-015-0359-z 
Table 1. List of sampling sites for Hikurangi Margin (TAN1004) and Bay of Plenty (TAN1206) (see Bowden et al. (2016)). Full names 1064 for named features are: Campbell Canyon, Honeycomb Canyon, Pahaua Canyon, Tauranga Canyon, White Island Canyon and Runaway 1065 Sea Valley. Unnamed seamount features are labelled according to the registration number of NIWA New Zealand seamounts database 1066 (e.g. 'SMT_310'). $\mathrm{N}=$ number of cores.

\begin{tabular}{|c|c|c|c|c|c|c|c|c|c|c|}
\hline Region & Voyage & Sampling date & Habitat & Site & Strata & Station & Depth (m) & Latitude (S) & Longitude (E) & $\mathbf{N}$ \\
\hline \multirow[t]{25}{*}{ Hikurangi Margin } & TAN1004 & April 2010 & Slope & 1 & 700 & 124 & 690 & 41.9857 & 174.6982 & 2 \\
\hline & & & & & 1500 & 128 & 1420 & 42.0485 & 174.7000 & 1 \\
\hline & & & & 2 & 1000 & 4 & 1046 & 41.6837 & 175.6642 & 3 \\
\hline & & & & & 1200 & 76 & 1282 & 41.6833 & 175.6500 & 2 \\
\hline & & & & & 1500 & 10 & 1561 & 41.7170 & 175.6748 & 2 \\
\hline & & & & 3 & 700 & 44 & 728 & 41.5258 & 175.8003 & 3 \\
\hline & & & & & 1000 & 41 & 942 & 41.5475 & 175.8398 & 3 \\
\hline & & & & & 1200 & 38 & 1121 & 41.5937 & 175.8532 & 3 \\
\hline & & & & & 1500 & 17 & 1514 & 41.6288 & 175.8682 & 2 \\
\hline & & & & & 1500 & 19 & 1553 & 41.6270 & 175.8637 & 1 \\
\hline & & & Canyon & Pahaua & 700 & 31 & 730 & 41.4962 & 175.6828 & 3 \\
\hline & & & & & 1000 & 27 & 1013 & 41.4983 & 175.7043 & 3 \\
\hline & & & & & 1200 & 22 & 1188 & 41.5100 & 175.7187 & 3 \\
\hline & & & & & 1500 & 12 & 1350 & 41.5508 & 175.7250 & 3 \\
\hline & & & & Honeycomb & 700 & 58 & 670 & 41.4080 & 175.8977 & 3 \\
\hline & & & & & 1000 & 53 & 948 & 41.4563 & 175.8970 & 1 \\
\hline & & & & & 1200 & 62 & 1171 & 41.4760 & 175.9477 & 3 \\
\hline & & & & Campbell & 700 & 92 & 683 & 41.8922 & 174.6347 & 2 \\
\hline & & & & & 1000 & 97 & 1011 & 41.9458 & 174.6173 & 1 \\
\hline & & & & & 1000 & 98 & 1012 & 41.9277 & 174.6165 & 2 \\
\hline & & & & & 1200 & 127 & 1177 & 42.1228 & 174.5397 & 1 \\
\hline & & & & & 1500 & 126 & 1495 & 42.1422 & 174.5492 & 3 \\
\hline & & & Seamount & 310 & 700 & 69 & 670 & 41.3353 & 176.1882 & 3 \\
\hline & & & & & 1000 & 72 & 985 & 41.3657 & 176.1958 & 3 \\
\hline & & & & 766 & 1000 & 130 & 894 & 42.1363 & 174.5737 & 1 \\
\hline
\end{tabular}




\begin{tabular}{|c|c|c|c|c|c|c|c|c|c|c|}
\hline Region & Voyage & Sampling date & Habitat & Site & Strata & Station & Depth (m) & Latitude (S) & Longitude (E) & $\mathbf{N}$ \\
\hline \multirow{6}{*}{ South Tower } & \multirow{8}{*}{ TAN0616 } & \multirow{8}{*}{ Nov 2006} & \multirow{8}{*}{ Seep } & \multirow{8}{*}{ Opouawe Bank } & 1500 & 129 & 1456 & 42.1345 & 174.5860 & 1 \\
\hline & & & & & 1500 & 132 & 1453 & 42.1345 & 174.5850 & 1 \\
\hline & & & & & 1000 & 84 & 1053 & 41.7832 & 175.4007 & 2 \\
\hline & & & & & 1000 & 86 & 1050 & 41.782 & 175.402 & 2 \\
\hline & & & & & 1000 & 116 & 1049 & 41.7885 & 175.4075 & 2 \\
\hline & & & & & 1000 & 118 & 1051 & 41.7893 & 175.4072 & 2 \\
\hline \multirow[t]{2}{*}{ North Tower } & & & & & 1000 & 112 & 1054 & 41.0782 & 175.4013 & 2 \\
\hline & & & & & 1000 & 123 & 1051 & 41.079 & 175.4075 & 2 \\
\hline \multirow[t]{21}{*}{ Bay of Plenty } & \multirow[t]{21}{*}{ TAN1206 } & \multirow[t]{21}{*}{ April 2012} & \multirow[t]{12}{*}{ Slope } & \multirow[t]{4}{*}{1} & 700 & 2 & 699 & $37^{\circ} 10.14$ & $176^{\circ} 39.58$ & 3 \\
\hline & & & & & 1000 & 5 & 998 & $37^{\circ} 06.74$ & $176^{\circ} 43.86$ & 3 \\
\hline & & & & & 1200 & 9 & 1193 & $37^{\circ} 03.48$ & $176^{\circ} 48.38$ & 3 \\
\hline & & & & & 1500 & 13 & 1501 & $37^{\circ} 55.35$ & $176^{\circ} 58.74$ & 3 \\
\hline & & & & \multirow[t]{4}{*}{2} & 700 & 52 & 710 & $37^{\circ} 30.26$ & $177^{\circ} 37.19$ & 3 \\
\hline & & & & & 1000 & 49 & 1004 & $37^{\circ} 25.90$ & $177^{\circ} 37.55$ & 3 \\
\hline & & & & & 1200 & 44 & 1202 & $37^{\circ} 21.95$ & $177^{\circ} 37.57$ & 3 \\
\hline & & & & & 1500 & 42 & 1501 & $37^{\circ} 14.50$ & $177^{\circ} 37.86$ & 3 \\
\hline & & & & \multirow[t]{4}{*}{3} & 700 & 185 & 726 & $37^{\circ} 22.84$ & $178^{\circ} 01.92$ & 3 \\
\hline & & & & & 1000 & 181 & 998 & $37^{\circ} 20.56$ & $178^{\circ} 01.71$ & 3 \\
\hline & & & & & 1200 & 178 & 1196 & $37^{\circ} 19.01$ & $178^{\circ} 01.42$ & 3 \\
\hline & & & & & 1500 & 175 & 1494 & $37^{\circ} 15.66$ & $178^{\circ} 00.23$ & 3 \\
\hline & & & \multirow[t]{9}{*}{ Canyon } & \multirow[t]{5}{*}{ Tauranga } & 700 & 125 & 697 & $37^{\circ} 28.48$ & $176^{\circ} 45.51$ & 3 \\
\hline & & & & & 1000 & 118 & 1083 & $37^{\circ} 20.00$ & $176^{\circ} 57.72$ & 3 \\
\hline & & & & & 1200 & 111 & 1221 & $37^{\circ} 15.05$ & $176^{\circ} 58.02$ & 2 \\
\hline & & & & & 1200 & 113 & 1222 & $37^{\circ} 15.06$ & $176^{\circ} 57.98$ & 1 \\
\hline & & & & & 1500 & 105 & 1486 & $37^{\circ} 11.35$ & $176^{\circ} 56.59$ & 3 \\
\hline & & & & \multirow[t]{4}{*}{ White Island } & 700 & 154 & 700 & $37^{\circ} 37.05$ & $177^{\circ} 13.46$ & 1 \\
\hline & & & & & 700 & 155 & 704 & $37^{\circ} 37.04$ & $177^{\circ} 13.48$ & 2 \\
\hline & & & & & 1000 & 150 & 1017 & $37^{\circ} 33.14$ & $177^{\circ} 16.21$ & 1 \\
\hline & & & & & 1000 & 151 & 1023 & $37^{\circ} 33.20$ & $177^{\circ} 16.10$ & 1 \\
\hline
\end{tabular}




\begin{tabular}{|c|c|c|c|c|c|c|c|c|c|c|}
\hline Region & Voyage & Sampling date & Habitat & Site & Strata & Station & Depth (m) & Latitude (S) & Longitude (E) & $\mathbf{N}$ \\
\hline & & & & & 1000 & 152 & 1031 & $37^{\circ} 33.17$ & $177^{\circ} 16.05$ & 1 \\
\hline & & & & & 1200 & 142 & 1200 & $37^{\circ} 31.75$ & $177^{\circ} 17.71$ & 1 \\
\hline & & & & & 1200 & 143 & 1202 & $37^{\circ} 31.77$ & $177^{\circ} 17.69$ & 2 \\
\hline & & & & & 1500 & 135 & 1523 & $37^{\circ} 26.59$ & $177^{\circ} 21.05$ & 3 \\
\hline & & & & Runaway & 700 & 55 & 705 & $37^{\circ} 25.85$ & $177^{\circ} 53.62$ & 3 \\
\hline & & & & & 1000 & 60 & 900 & $37^{\circ} 24.17$ & $177^{\circ} 52.65$ & 2 \\
\hline & & & & & 1000 & 61 & 870 & $37^{\circ} 24.20$ & $177^{\circ} 52.67$ & 1 \\
\hline & & & & & 1200 & 65 & 1254 & $37^{\circ} 21.86$ & $177^{\circ} 52.59$ & 1 \\
\hline & & & & & 1200 & 66 & 1254 & $37^{\circ} 21.86$ & $177^{\circ} 52.59$ & 2 \\
\hline & & & & & 1500 & 70 & 1518 & $37^{\circ} 18.13$ & $177^{\circ} 52.27$ & 3 \\
\hline
\end{tabular}

1067

1068 
1069 Table 2. SIMPER analysis results showing meiofaunal taxa accounting for community 1070 dissimilarity between the Hikurangi Margin and Bay of Plenty study regions (cut-off applied at $107190 \%$ contribution). [Av.abund = average meiofauna abundance (individual $10 \mathrm{~cm}^{-2}$ ), Av.Diss = 1072 average dissimilarity, Diss/SD $=$ Dissimilarity/Standard Deviation, Contrib $\%=\%$ contribution to 1073 overall dissimilarity, Cum. $\%=\%$ cumulative dissimilarity]. Higher average abundance are shown 1074 in bold.

\begin{tabular}{lrrrrrr}
\hline Taxon & Av.Abund & Av.Abund & Av.Diss & Diss/SD & Contrib\% & Cum.\% \\
\hline Kinorhynchs & Hikurangi Margin & Bay of Plenty & & & & \\
Ostracods & $\mathbf{6 . 6}$ & 1.5 & 2.96 & 1.31 & 13.25 & 13.25 \\
Nematodes & $\mathbf{2 . 9}$ & 0.9 & 2.66 & 1.25 & 11.89 & 25.15 \\
Copepods & $\mathbf{6 6 3 . 4}$ & 446.5 & 2.32 & 1.5 & 10.39 & 35.54 \\
Tanaidaceans & $\mathbf{5 8 . 1}$ & 21.0 & 2.25 & 1.54 & 10.06 & 45.6 \\
Nauplii & $\mathbf{1 . 1}$ & 0.4 & 2.18 & 1.11 & 9.75 & 55.36 \\
Tardigrades & $\mathbf{3 8 . 4}$ & 16.6 & 2.18 & 1.39 & 9.74 & 65.1 \\
Annelids & 0 & $\mathbf{1 . 0}$ & 1.95 & 0.95 & 8.72 & 73.82 \\
Isopods & $\mathbf{1 4 . 0}$ & 4.4 & 1.84 & 1.53 & 8.25 & 82.06 \\
Amphipods & $\mathbf{0 . 5 0}$ & 0.3 & 1.34 & 0.74 & 6.01 & 88.08 \\
\hline
\end{tabular}


1076 Table 3. SIMPER analysis results showing meiofaunal taxa accounting for community 1077 dissimilarity between 0-1 and 1-5 cm sediment depth layers in the Hikurangi Margin study region 1078 (cut-off applied at 90\% contribution). [Av.abund = average meiofauna abundance (individual 10 $1079 \mathrm{~cm}^{-2}$ ), Av.Diss = average dissimilarity, Diss $/ \mathrm{SD}=$ Dissimilarity $/$ Standard Deviation, Contrib $\%=$ $1080 \%$ contribution to overall dissimilarity, Cum. $\%=\%$ cumulative dissimilarity]. Higher average 1081 abundance are shown in bold.

\begin{tabular}{lrrrrrr}
\hline Taxon & Av.Abund & Av.Abund & Av.Diss & Diss/SD & Contrib\% & Cum.\% \\
\hline 0-1cm & \multicolumn{1}{c}{$1-5 \mathrm{~cm}$} & & & & & \\
\hline Nauplii & $\mathbf{2 8 . 7}$ & 9.7 & 4.06 & 1.23 & 16.78 & 16.78 \\
Kinorhynchs & $\mathbf{4 . 3}$ & 2.3 & 3.35 & 1.2 & 13.85 & 30.63 \\
Copepods & $\mathbf{3 9 . 1}$ & 19.0 & 3.21 & 1.08 & 13.26 & 43.89 \\
Ostracods & $\mathbf{2 . 2}$ & 0.7 & 3.07 & 1.17 & 12.67 & 56.56 \\
Nematodes & 248.3 & $\mathbf{4 1 5 . 2}$ & 3.02 & 1.34 & 12.48 & 69.05 \\
Tanaidaceans & $\mathbf{0 . 7}$ & 0.8 & 2.13 & 0.93 & 8.81 & 77.86 \\
Annelids & 4.9 & $\mathbf{9 . 1}$ & 2.09 & 1.03 & 8.62 & 86.48 \\
Isopods & 0.2 & $\mathbf{0 . 3}$ & 1.1 & 0.58 & 4.52 & 91 \\
\hline
\end{tabular}


1083 Table 4. DistLM analysis results showing correlations between environmental variables and 1084 meiofaunal attributes for the Hikurangi Margin region. $\left[\mathrm{P}=\right.$ probablity, $\mathrm{R}^{2}=$ proportion of 1085 explained variation attributable to each variable, $\mathrm{R}^{2}(\mathrm{cum})=$ cumulative proportion of variation, 1086 rs.df $=$ residual degrees of freedom, Slope STD $=$ Standard deviation of slope based on 3, 5, 7, 15 1087 grid cell focal mean, STD $=$ Standard deviation of depth, Vrm $=$ terrain rugosity, $(+/-)=$ 1088 positive/negative relationship].

\begin{tabular}{lcclcrrr}
\hline Variable & $\mathrm{P}$ & $\mathrm{R} 2$ & Variable & $\mathrm{P}$ & $\mathrm{R}^{2}$ & $\mathrm{R}^{2}$ cum & rs.df \\
\hline MARGINAL TESTS & & \multicolumn{7}{c}{ SEQUENTIAL TESTS } \\
\hline Abundance 0-1cm & & \multicolumn{7}{c}{ Abundance 0-1cm } \\
(-) Profile curvature & 0.0073 & 0.12 & (-) Profile curvature & 0.0075 & 0.12 & 0.12 & 57 \\
(+) Water depth & 0.0074 & 0.12 & (+) Water depth & 0.0087 & 0.10 & 0.22 & 56 \\
(-) Curvature & 0.0124 & 0.11 & (-) $\% \mathrm{CaCO}_{3}$ & 0.0295 & 0.06 & 0.28 & 55
\end{tabular}

\section{Abundance 1-5cm}

(+) Slope STD15

$(+)$ Vrm05

(+) Phaeopigment

(-) Water depth

$(+)$ Skewness

(-) Curvature

(+) STD15

$(+)$ Particle size diversity

\section{Diversity 0-1cm}

(-) Mean particle size

(-) Particle size diversity

(-) Fishing intensity

\section{Diversity 1-5cm}
(-) Curvature
0.0010
0.16
(-) Profile curvature
0.0039
0.14
(+) Phaeopigment
$0.0068 \quad 0.13$
(-) $\% \mathrm{CaCO}_{3}$
0.0073
0.12

\section{Community structure $0-1 \mathrm{~cm}$}

Profile curvature

$\begin{array}{ll}0.0008 & 0.08\end{array}$

Curvature

0.0017

0.0145

0.07

Depth

Skewness

0.0227

0.05

$\% \mathrm{CaCO}_{3}$

$0.0466 \quad 0.04$

\section{Abundance 1-5cm}

$\begin{array}{lllll}\text { (+) Slope STD15 } & 0.0001 & 0.41 & 0.41 & 57 \\ \text { (-) } \% \mathrm{CaCO}_{3} & 0.0007 & 0.12 & 0.53 & 56 \\ \text { (+) } \mathrm{Vrm} 05 & 0.0013 & 0.11 & 0.64 & 55 \\ \text { (+) Slope STD03 } & 0.0005 & 0.07 & 0.71 & 54\end{array}$

\section{Diversity 0-1 cm}

$\begin{array}{lllll}(-) & \text { Mean particle size } \quad 0.0418 & 0.07 & 0.07 & 57\end{array}$

\section{Diversity 1-5cm}

$\begin{array}{lllll}\text { (-) Curvature } & 0.0019 & 0.16 & 0.16 & 57\end{array}$

\section{Community structure 0-1cm}

Community structure $1-5 \mathrm{~cm}$

Curvature

$\begin{array}{ll}0.0020 & 0.09\end{array}$

Phaeopigment

$0.0023 \quad 0.08$

$\begin{array}{llll}0.0008 & 0.08 & 0.08 & 57 \\ 0.0057 & 0.05 & 0.18 & 55 \\ 0.0207 & 0.04 & 0.12 & 56 \\ 0.0293 & 0.03 & 0.24 & 53\end{array}$

\section{Community structure $1-5 \mathrm{~cm}$}

Curvature

$0.09 \quad 57$

Slope STD15

$0.0025 \quad 0.08$

$0.16 \quad 56$ $\begin{array}{ll}0.0021 & 0.09\end{array}$ 


\begin{tabular}{llllllll} 
Slope $\mathrm{STD} 15$ & 0.0022 & 0.08 & $\% \mathrm{CaCO}_{3}$ & 0.0074 & 0.05 & 0.21 & 55 \\
$\% \mathrm{CaCO}_{3}$ & 0.0106 & 0.06 & & & & & \\
Profile curvature & 0.0123 & 0.06 & & & & & \\
Vrm05 & 0.0131 & 0.06 & & & & \\
Depth & 0.0232 & 0.05 & & & & \\
\hline
\end{tabular}


1090 Table 5. SIMPER analysis results showing meiofaunal taxa accounting for community 1091 dissimilarity between different water and sediment depths for the Bay of Plenty study region (cut1092 off applied at 70\% contribution). [Av.abund = average meiofauna abundance (individual $10 \mathrm{~cm}^{-2}$ ), 1093 Av.Diss $=$ average dissimilarity, Diss $/ \mathrm{SD}=$ Dissimilarity $/$ Standard Deviation, Contrib $\%=\%$ 1094 contribution to overall dissimilarity, Cum. $\%=\%$ cumulative dissimilarity]. Higher average 1095 abundance are shown in bold.

\begin{tabular}{lrrrrrr}
\hline Taxon & Av.Abund & Av.Abund & Av.Diss & Diss/SD & Contrib\% & Cum.\% \\
\hline Water depths & $700 m$ & $1200 m$ & & & & \\
Nauplii & $\mathbf{2 4 . 4}$ & 12.0 & 4.05 & 1.17 & 17.02 & 17.02 \\
Annelids & $\mathbf{5 . 8}$ & 3.2 & 3.19 & 1.08 & 13.4 & 30.42 \\
Kinorhynchs & $\mathbf{1 . 7}$ & 1.2 & 2.78 & 0.94 & 11.65 & 42.07 \\
Tardigrades & $\mathbf{1 . 6}$ & 0.6 & 2.57 & 0.89 & 10.81 & 52.89 \\
Nematodes & $\mathbf{4 4 1 . 6}$ & 385.1 & 2.52 & 1.31 & 10.59 & 63.48 \\
Copepods & $\mathbf{2 8 . 0}$ & 19.4 & 2.47 & 1.38 & 10.36 & 73.84 \\
& & & & & & \\
& $700 m$ & $1500 m$ & & & & \\
Nauplii & $\mathbf{2 4 . 4}$ & 14.1 & 3.94 & 1.17 & 16.52 & 16.52 \\
Copepods & $\mathbf{2 8 . 0}$ & 16.4 & 3.35 & 1.03 & 14.04 & 30.57 \\
Kinorhynchs & $\mathbf{1 . 7}$ & 1.5 & 2.88 & 0.97 & 12.08 & 42.65 \\
Nematodes & $\mathbf{4 4 1 . 6}$ & 431.3 & 2.73 & 1.31 & 11.44 & 54.08 \\
Tardigrades & $\mathbf{1 . 6}$ & 0.9 & 2.72 & 0.95 & 11.41 & 65.49 \\
Ostracods & $\mathbf{1 . 6}$ & 0.7 & 2.3 & 0.83 & 9.64 & 75.13 \\
& & & & & & \\
Sediment depths & $0-1 \mathrm{~cm}$ & $1-5 \mathrm{~cm}$ & & & & \\
Nauplii & $\mathbf{1 3 . 6}$ & 3.0 & 5.06 & 1.34 & 19.24 & 19.24 \\
Copepods & $\mathbf{1 5 . 2}$ & 5.8 & 3.28 & 1.23 & 12.49 & 31.73 \\
Kinorhynchs & $\mathbf{1 . 2}$ & 0.3 & 3.23 & 1.03 & 12.27 & 44 \\
Nematodes & 184.9 & $\mathbf{2 6 1 . 6}$ & 2.99 & 1.3 & 11.39 & 55.4 \\
Tardigrades & $\mathbf{0 . 8}$ & 0.2 & 2.74 & 0.94 & 10.42 & 65.82 \\
Annelids & $\mathbf{2 . 4}$ & 2.1 & 2.51 & 0.9 & 9.53 & 75.35 \\
\hline
\end{tabular}


1097 Table 6. DistLM analysis results showing correlations between environmental variables and 1098 meiofaunal community attributes in the Bay of Plenty region. $\left[\mathrm{P}=\right.$ probablity, $\mathrm{R}^{2}=$ proportion of 1099 explained variation attributable to each variable, $\mathrm{R}^{2}(\mathrm{cum})=$ cumulative proportion of variation, 1100 rs.df $=$ residual degrees of freedom, Slope STD $=$ Standard deviation of slope based on 3, 5, 7, 15 1101 grid cell focal mean, STD = Standard deviation of depth, $(+/-)=$ positive/negative relationship].

\begin{tabular}{|c|c|c|c|c|c|c|c|}
\hline Variable & $\mathrm{P}$ & $\mathrm{R}^{2}$ & Variable & $\mathrm{P}$ & $\mathrm{R}^{2}$ & $\mathrm{R}^{2}$ cum & rs.df \\
\hline MARGINAL TESTS & & & \multicolumn{5}{|l|}{ SEQUENTIAL TESTS } \\
\hline $\begin{array}{l}\text { Abundance } \mathbf{0}-\mathbf{1 c m} \\
(+) \text { Surface chlorophyll } \\
\text { concentration }\end{array}$ & 0.0125 & 0.09 & \multirow{2}{*}{$\begin{array}{l}\text { Abundance } \mathbf{0}-\mathbf{1} \mathbf{c m} \\
(+) \text { Surface chlorophyll } \\
\text { concentration } \\
(+) \text { Plan curvature }\end{array}$} & 0.0119 & 0.09 & 0.09 & 69 \\
\hline \multirow[t]{4}{*}{$(-) \% \mathrm{CaCO}_{3}$} & 0.0140 & 0.09 & & 0.0172 & 0.09 & 0.17 & 68 \\
\hline & & & $(+) \% \mathrm{OC}$ & 0.0170 & 0.07 & 0.24 & 67 \\
\hline & & & (-) Skewness & 0.0356 & 0.05 & 0.29 & 66 \\
\hline & & & (+) Slope STD07 & 0.0265 & 0.05 & 0.40 & 62 \\
\hline
\end{tabular}

\section{Abundance 1-5 cm}
$(+) \% \mathrm{OC}$
$(+)$ Kurtosis
(+) Phaeopigment
(+) \%Silt/clay
(-) Sorting

$\begin{array}{ll}0.0001 & 0.18 \\ 0.0012 & 0.14 \\ 0.0057 & 0.10 \\ 0.0141 & 0.08 \\ 0.0163 & 0.08\end{array}$

Diversity 0-1 cm

(+) Surface chlorophyll $\quad 0.0053 \quad 0.10$ concentration
(-) Water depth
$\begin{array}{ll}0.0107 & 0.09\end{array}$
(+) Phaeopigment
$\begin{array}{ll}0.0100 & 0.09\end{array}$

\section{Diversity 1-5 cm}
$(+)$ Kurtosis
$\begin{array}{ll}0.0014 & 0.15\end{array}$
$(+) \% \mathrm{OC}$
$\begin{array}{ll}0.0106 & 0.09\end{array}$
$(+)$ Skewness
$\begin{array}{ll}0.0220 & 0.07\end{array}$
(+) \%Silt/clay
$0.0335 \quad 0.06$
(+) $\% \mathrm{OM}$
$0.0369 \quad 0.06$

\section{Community structure 0-1 cm}

Water depth

Surface chlorophyll

concentration

Plan curvature

$\%$ Silt/clay

Phaeopigment

$\begin{array}{ll}0.0056 & 0.04\end{array}$

$\begin{array}{ll}0.0110 & 0.04\end{array}$

Sorting

$\begin{array}{ll}0.0174 & 0.03\end{array}$

$\begin{array}{ll}0.0294 & 0.03\end{array}$

$\begin{array}{ll}0.0306 & 0.03\end{array}$

$\% \mathrm{OM}$

$\begin{array}{ll}0.0418 & 0.03\end{array}$

$0.0403 \quad 0.03$

\section{Abundance 1-5 cm}

$\begin{array}{lllll}(+) \text { \%OC } & 0.0005 & 0.18 & 0.18 & 69 \\ \text { (+) Kurtosis } & 0.0115 & 0.07 & 0.26 & 68 \\ \text { (+) Range07 } & 0.0212 & 0.05 & 0.53 & 53\end{array}$

\section{Diversity 0-1 cm}

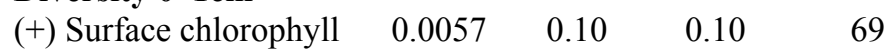
concentration
(-) Sorting
$0.0244 \quad 0.07$
0.17
68

\section{Diversity $1-5 \mathrm{~cm}$}

\begin{tabular}{|c|c|}
\hline$(+)$ Kurtosis & 0.0013 \\
\hline
\end{tabular}

\section{Community structure 0-1 cm}

Water depth

Plan curvature

$\% \mathrm{OM}$

Kurtosis
0.0062

0.0082

0.0220

0.0302
0.04

0.03

0.04

0.07

69

68

$0.14 \quad 66$

$0.28 \quad 59$


Community structure $1-5 \mathrm{~cm}$

Kurtosis

$\%$ Silt/clay

Skewness

$\% \mathrm{OC}$

Sorting

$\% \mathrm{OM}$

Phaeopigment

\section{Community structure $1-5 \mathrm{~cm}$}

Kurtosis

$\begin{array}{llll}0.0004 & 0.06 & 0.06 & 69\end{array}$

$\% \mathrm{OC}$

$0.0448 \quad 0.03$

$0.09 \quad 68$

Surface chlorophyll

0.0475

0.03

0.16

65
$0.0091 \quad 0.04$

$0.0252 \quad 0.03$

$0.0276 \quad 0.03$

$0.0274 \quad 0.03$ 
1103 Table 7. Results of the SIMPER analysis showing meiofauna taxa accounting for community 1104 dissimilarity between seep and other habitats for the Hikurangi Margin study region (cut-off 1105 applied at 90\% contribution). [Av.abund = average meiofauna abundance (individual $10 \mathrm{~cm}^{-2}$ ), 1106 Av.Diss $=$ average dissimilarity, Diss $/ \mathrm{SD}=$ Dissimilarity $/$ Standard Deviation, Contrib $\%=\%$ 1107 contribution to overall dissimilarity, Cum. $\%=\%$ cumulative dissimilarity]. Higher average 1108 abundance are shown in bold.

\begin{tabular}{|c|c|c|c|c|c|c|}
\hline Taxon & Av.Abund & Av.Abund & Av.Diss & Diss/SD & Contrib\% & Cum.\% \\
\hline & Seamount & Seep & & & & \\
\hline Nauplii & 8.6 & 30.3 & 4.04 & 1.19 & 14.73 & 14.7 \\
\hline Amphipods & 0.2 & 3.6 & 3.59 & 1.32 & 13.07 & 27.8 \\
\hline Copepods & 16.9 & 36.8 & 3.3 & 1.13 & 12.01 & 39.8 \\
\hline Tanaidaceans & 0.3 & 2.5 & 3.2 & 1.27 & 11.65 & 51.5 \\
\hline Kinorhynchs & 2.4 & 2.6 & 3.06 & 1.15 & 11.15 & 62.6 \\
\hline Ostracods & 0.6 & 1.5 & 2.74 & 1.13 & 9.98 & 72.6 \\
\hline Bivalves & 0 & 1.0 & 2.46 & 1.04 & 8.97 & 81.6 \\
\hline \multirow[t]{2}{*}{ Nematodes } & 213.4 & 268.2 & 2.36 & 1.39 & 8.6 & 90.2 \\
\hline & Canyon & Seep & & & & \\
\hline Nauplii & 19.8 & 30.3 & 3.8 & 1.21 & 14.28 & 14.3 \\
\hline Amphipods & 0.2 & 3.6 & 3.4 & 1.35 & 12.76 & 27.0 \\
\hline Kinorhynchs & 4.3 & 2.6 & 3.07 & 1.17 & 11.54 & 38.6 \\
\hline Tanaidaceans & 0.5 & 2.5 & 2.87 & 1.24 & 10.8 & 49.4 \\
\hline Copepods & 30.3 & 36.8 & 2.87 & 1.27 & 10.8 & 60.2 \\
\hline Ostracods & 1.8 & 1.5 & 2.71 & 1.16 & 10.19 & 70.4 \\
\hline Nematodes & 398.5 & 268.2 & 2.69 & 1.31 & 10.1 & 80.5 \\
\hline Bivalves & 0.4 & 1.0 & 2.32 & 1.06 & 8.74 & 89.2 \\
\hline \multirow[t]{2}{*}{ Annelids } & 9.1 & 9.3 & 1.66 & 1.11 & 6.25 & 95.5 \\
\hline & Slope & Seep & & & & \\
\hline Amphipods & 0.2 & 3.6 & 3.45 & 1.36 & 13.15 & 13.2 \\
\hline Nauplii & 22.6 & 30.3 & 3.32 & 1.24 & 12.68 & 25.8 \\
\hline Tanaidaceans & 0.5 & 2.5 & 3.01 & 1.28 & 11.47 & 37.3 \\
\hline Kinorhynchs & 3.6 & 2.6 & 2.89 & 1.14 & 11.04 & 48.4 \\
\hline Copepods & 34.9 & 36.8 & 2.89 & 1.17 & 11.01 & 59.4 \\
\hline Ostracods & 1.7 & 1.5 & 2.65 & 1.16 & 10.1 & 69.5 \\
\hline Nematodes & 315.5 & 268.2 & 2.38 & 1.27 & 9.07 & 78.5 \\
\hline Bivalves & 0.03 & 1.0 & 2.28 & 1.04 & 8.7 & 87.2 \\
\hline Annelids & 5.3 & 9.3 & 1.83 & 0.83 & 6.99 & 94.2 \\
\hline
\end{tabular}



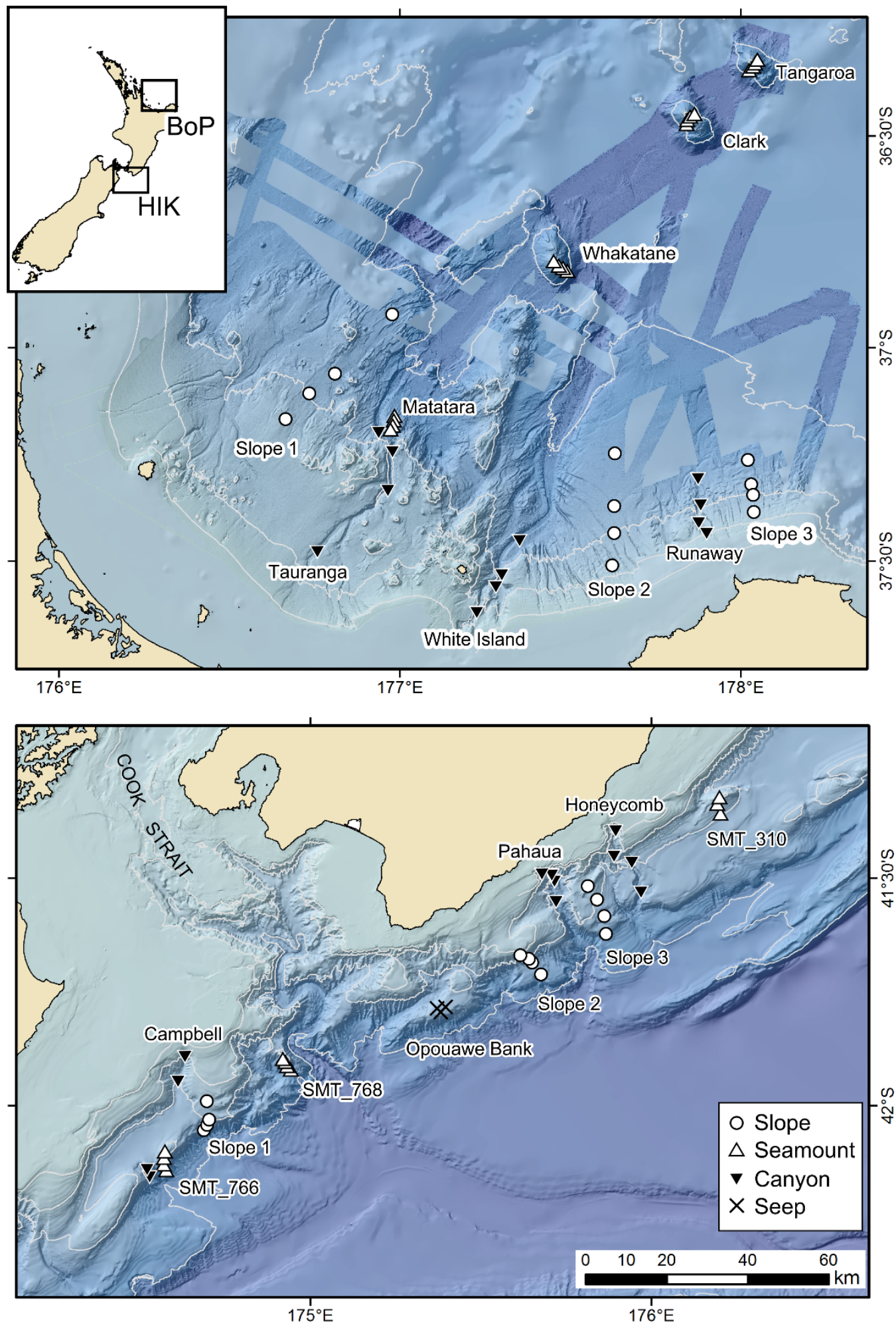

1111 Figure 1. Map showing sampling sites and stations in the Bay of Plenty (BoP, top) and Hikurangi 1112 Margin (HIK, bottom) study regions and their relative locations in New Zealand (inset). Scale bar applies to both regional maps. Not all sites and stations could be sampled in the present study. 
1114 Refer to Table 1 for a list of sites and stations where meiofaunal samples were obtained. The blue 1115 strips in the top panel show multibeam lines where bathymetry is more detailed than the underlying 1116 pale blue.
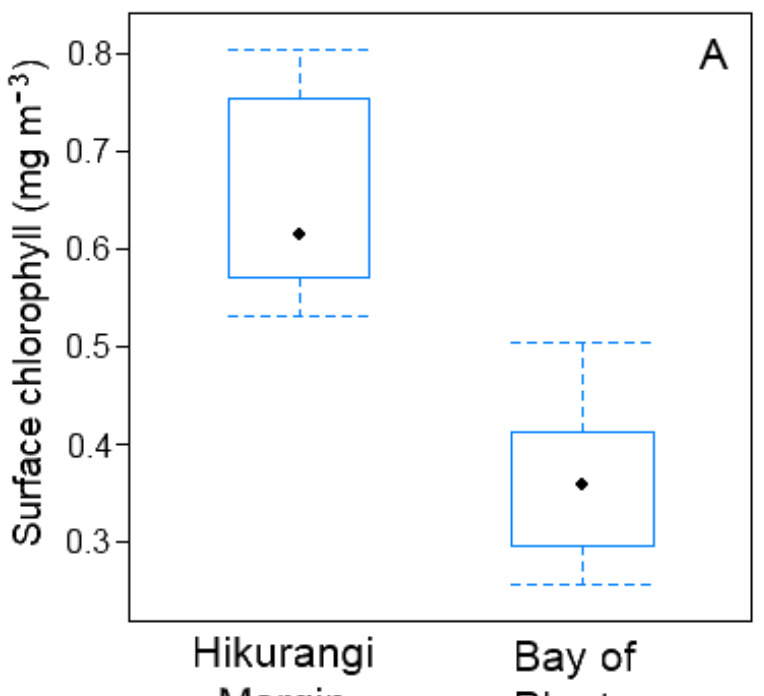

Margin Plenty

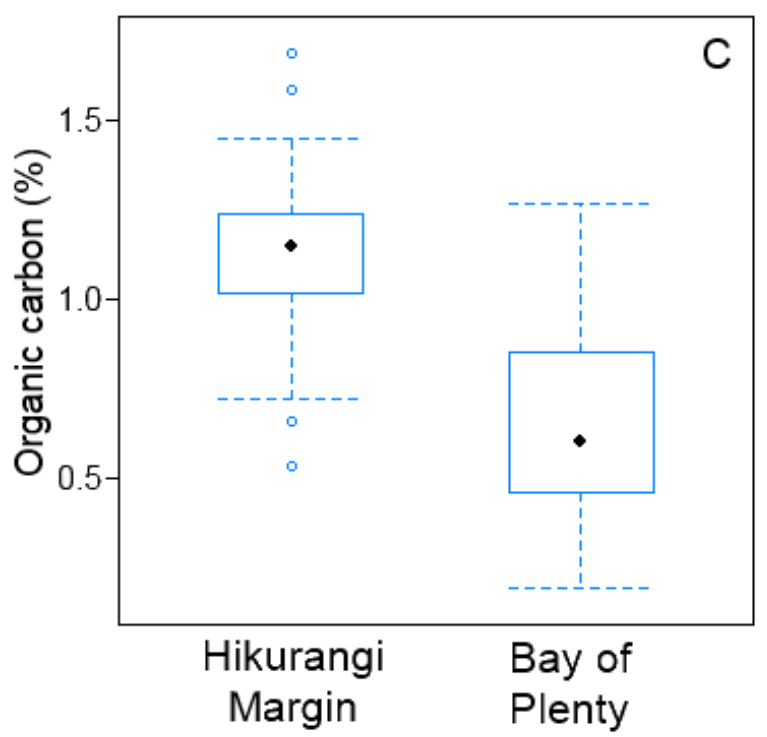

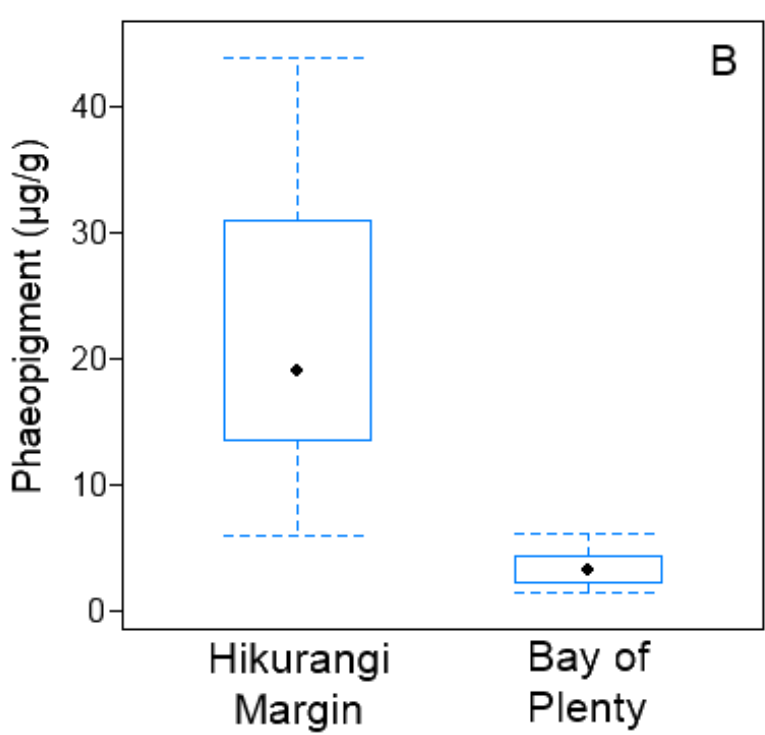

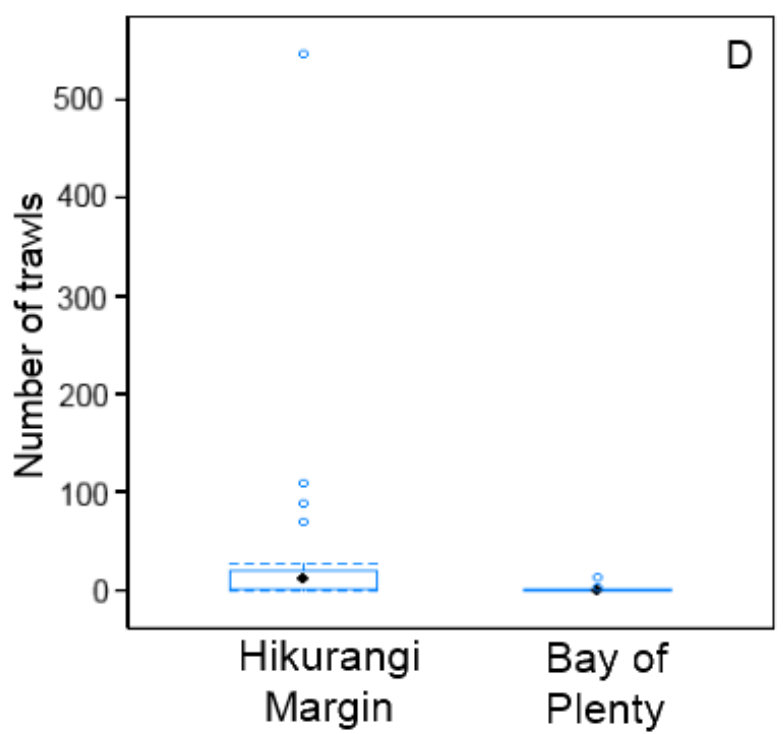

1117

1118

1119

1120

1121

Figure 2. Comparison of variables responsible for most of environmental dissimilarity between the Hikurangi Margin and Bay of Plenty study regions. A. Mean surface chlorophyll concentration; B. Sediment phaeopigment concentration; C. Sediment organic carbon content; D. Fishing intensity. (Environmental data first published in Bowden et al. (2016)). 


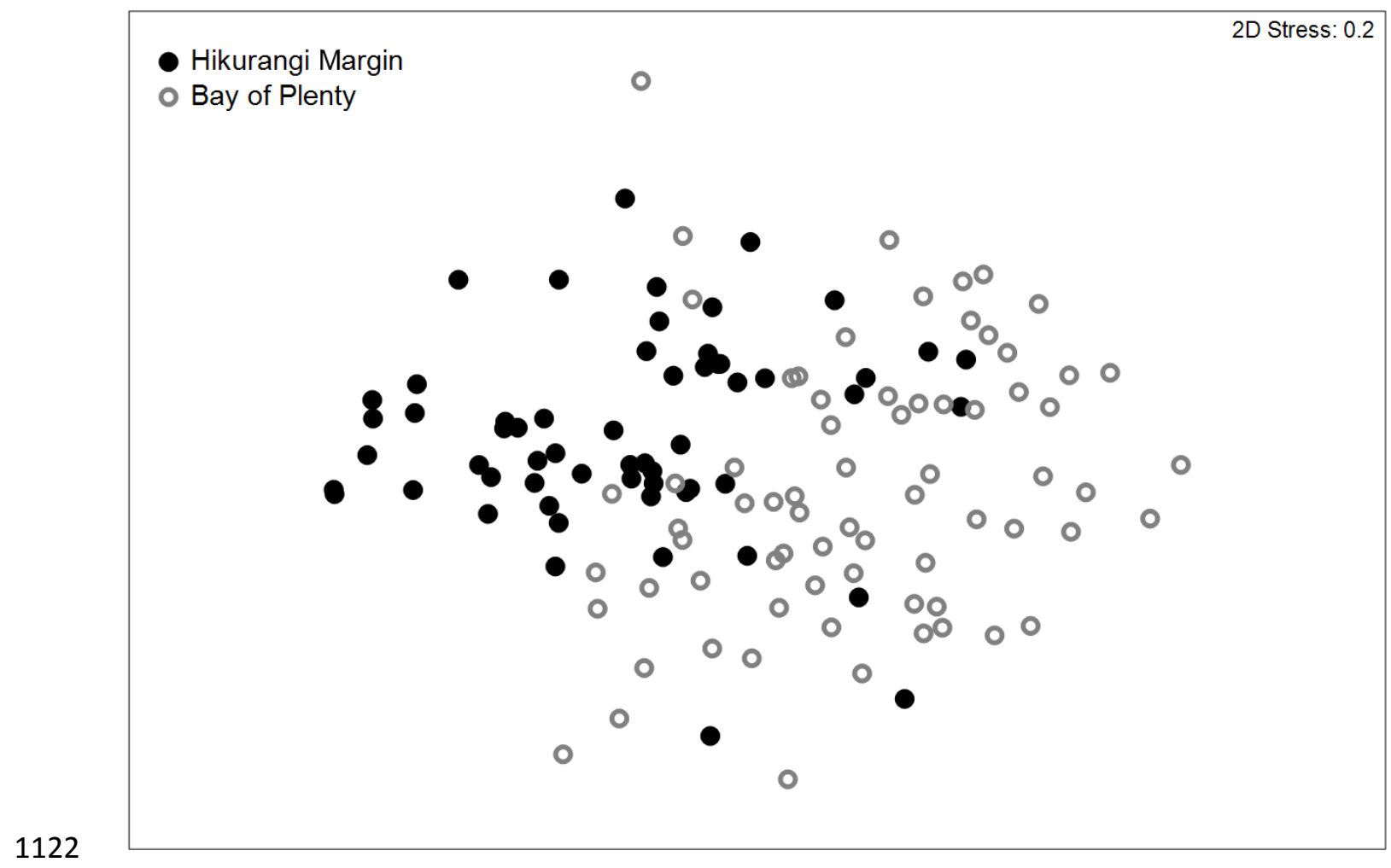

1123 Figure 3. Two-dimensional MDS ordination plot of meiofaunal community structure at the 1124 Hikurangi Margin and Bay of Plenty study regions. 


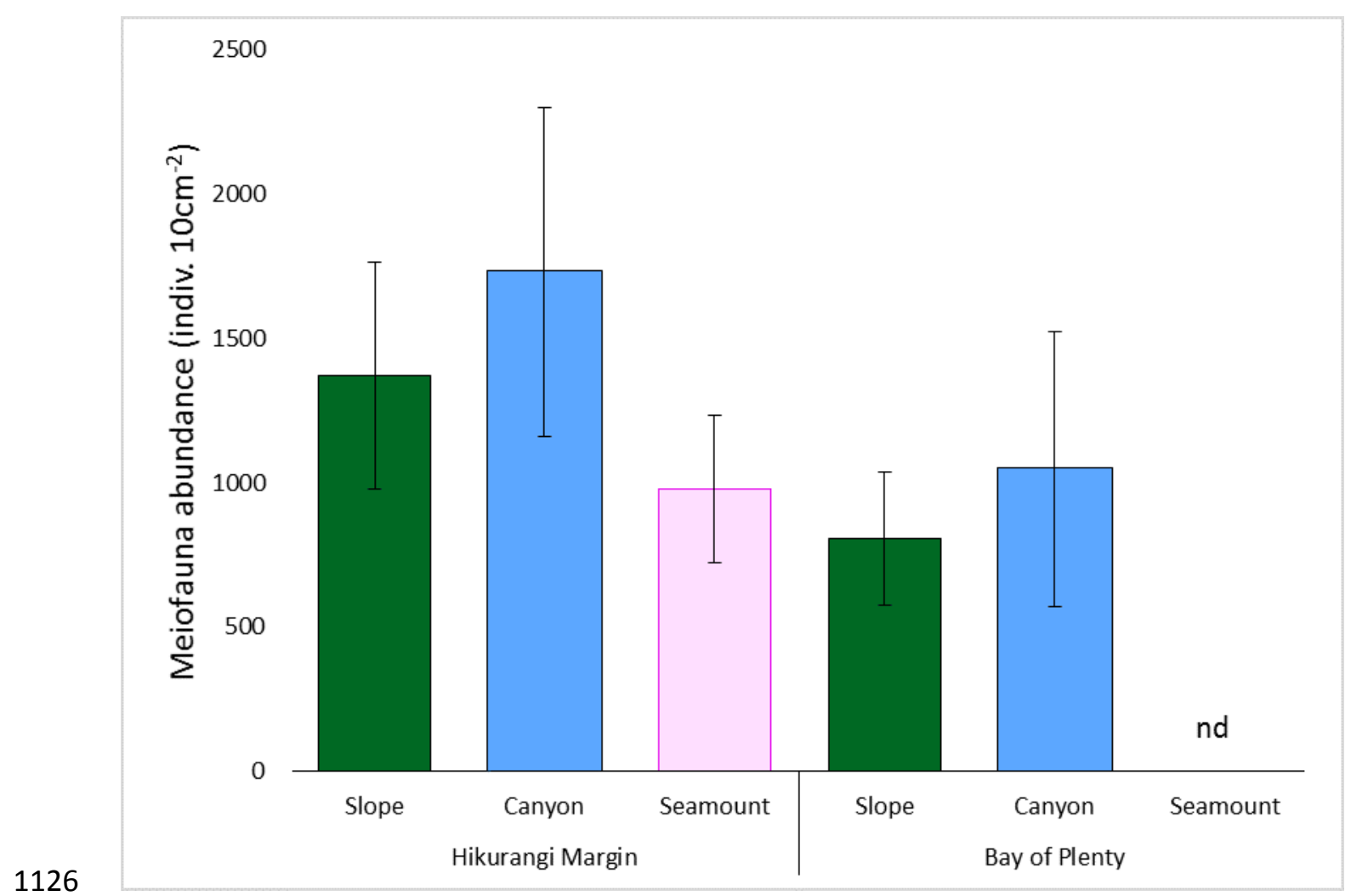

1127 Figure 4. Comparison of average total meiofaunal abundance among habitats (slope, canyon and seamount) in Hikurangi Margin and Bay of Plenty. Data are means $( \pm \mathrm{SD})$. nd $=$ no data. 
Hikurangi Margin
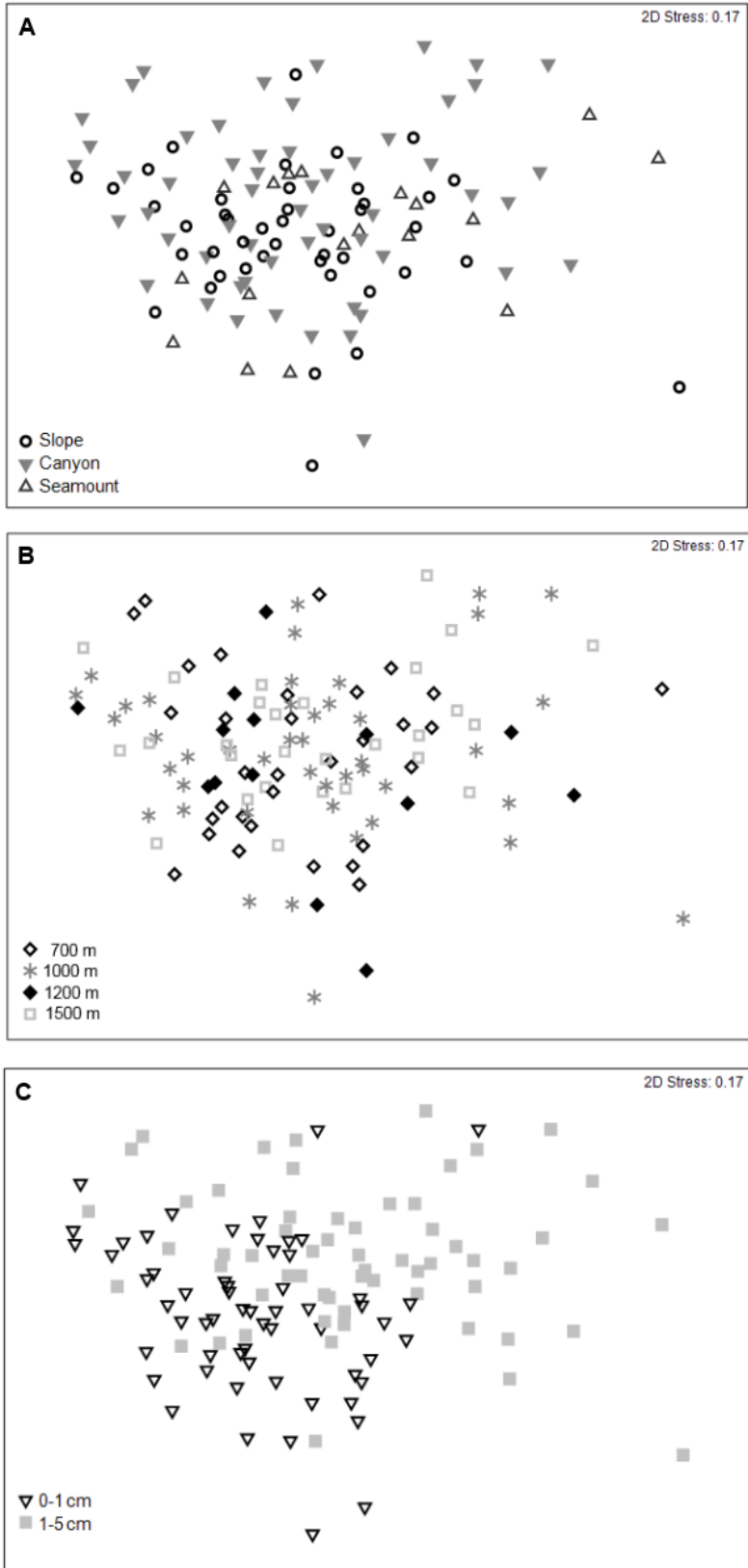

Bay of Plenty
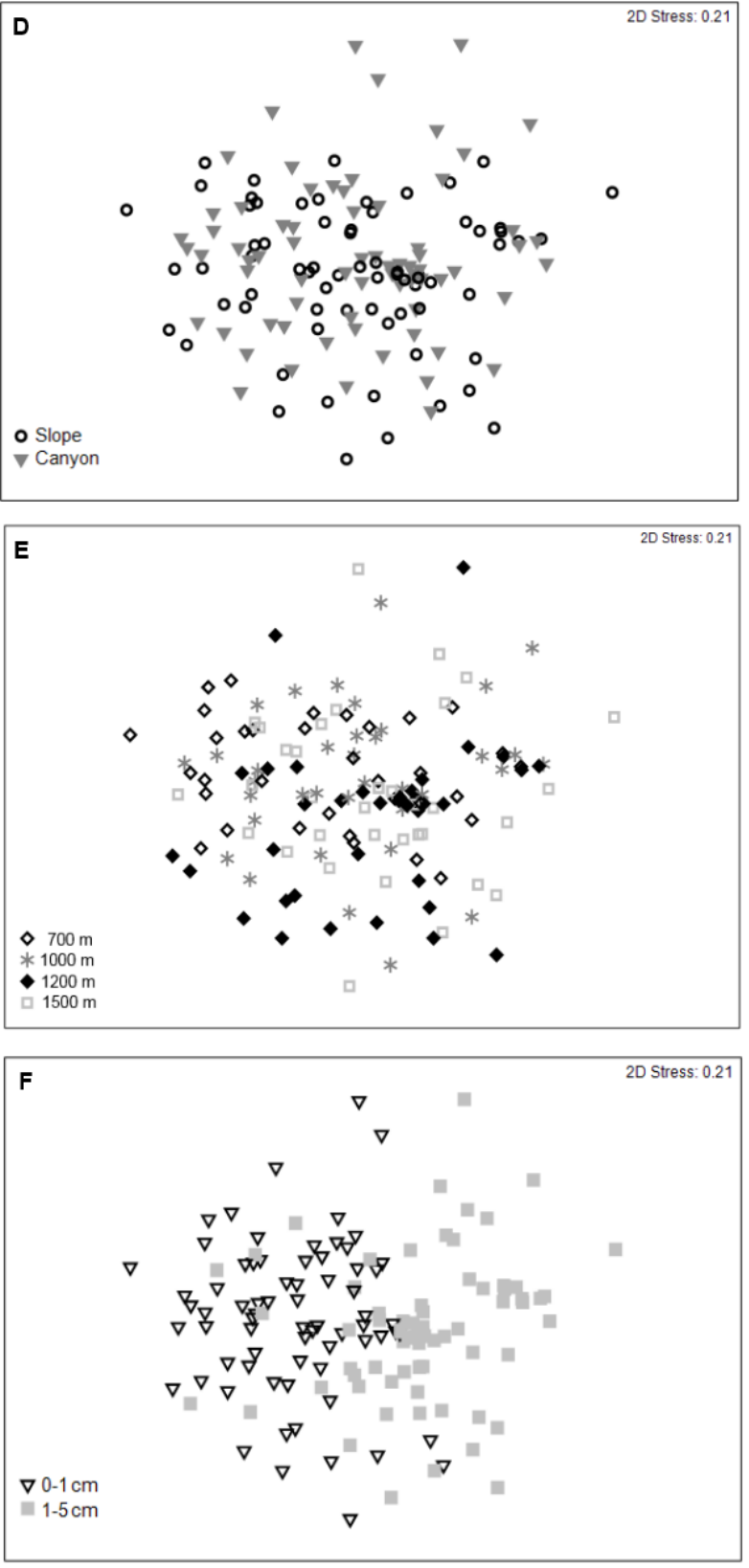

Figure 5. Two-dimensional MDS ordination of meiofaunal community structure at the study regions. Hikurangi Margin: A. Habitat; B. Water depth; C. Sediment depth; Bay of Plenty: D. Habitat; E. Water depth; F. Sediment depth. 
Hikurangi Margin
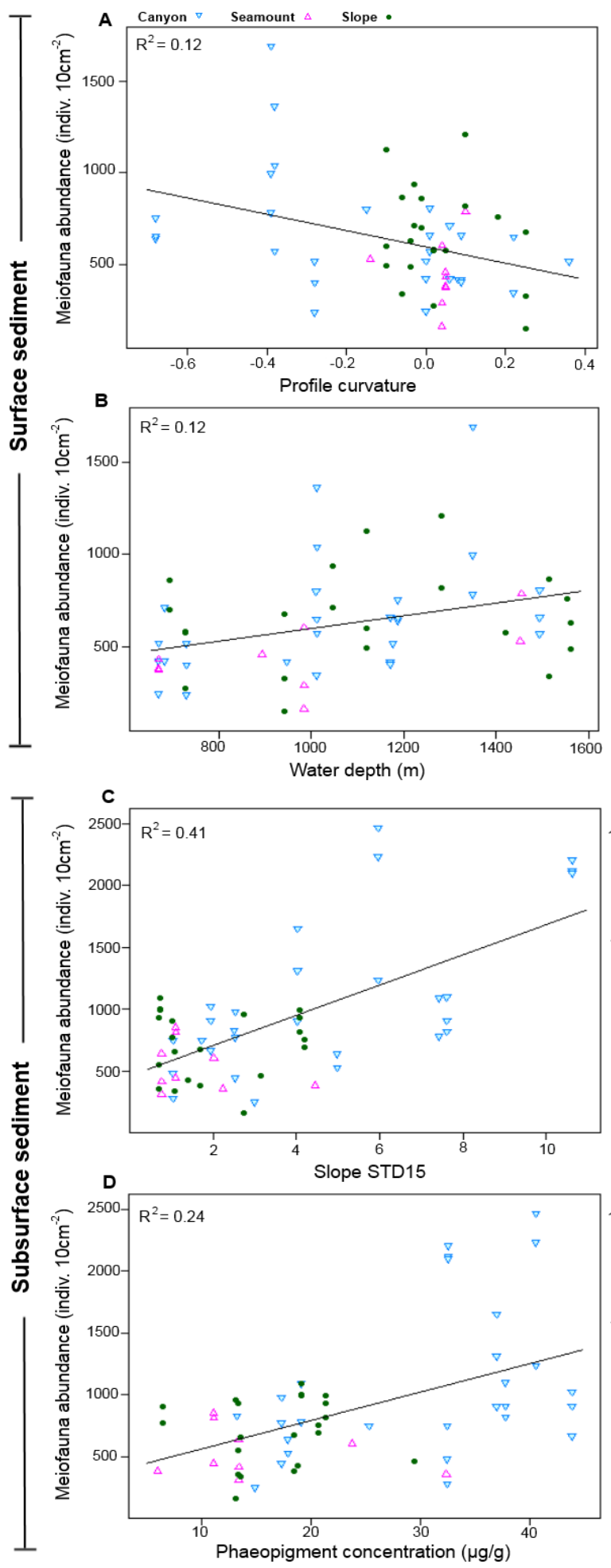

Bay of Plenty
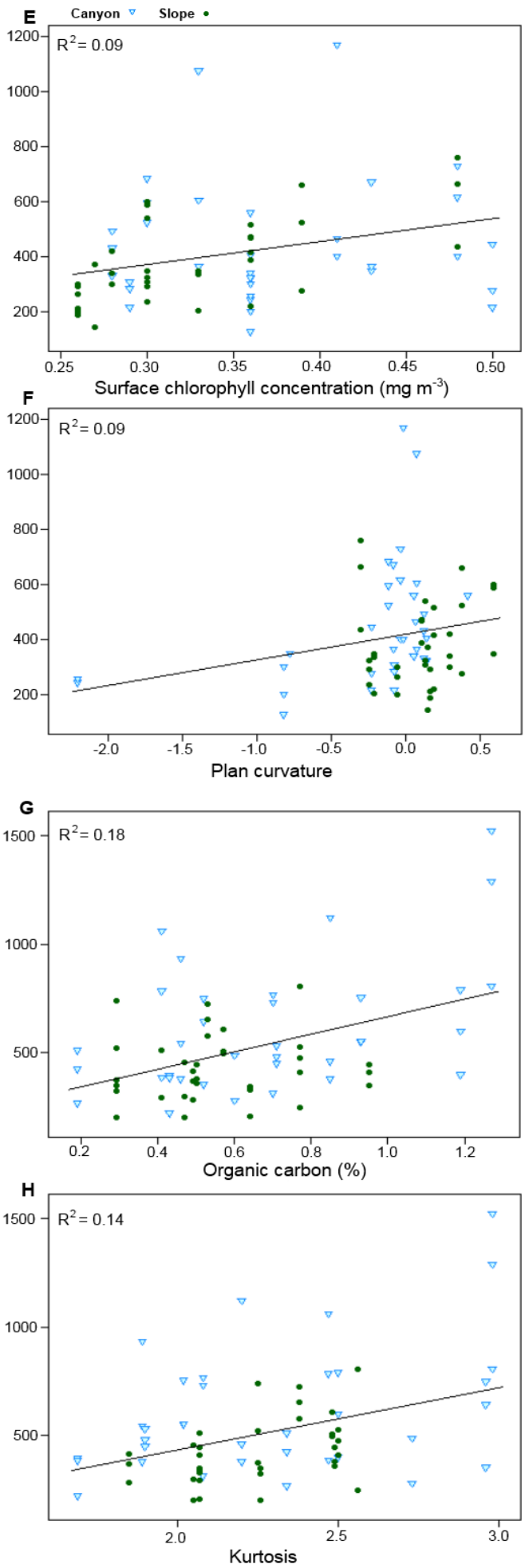

Figure 6. Selection of statistically significant $(\mathrm{P}<0.05)$ correlations between environmental variables and meiofaunal abundance at different sediment layers in the Hikurangi Margin and Bay of Plenty regions. Hikurangi Margin, surface sediment $(0-1 \mathrm{~cm})$ : A. Profile curvature; B. Water 
1137 depth $(\mathrm{m})$; Subsurface sediment $(1-5 \mathrm{~cm})$ : C. Standard deviation of the slope (15 grid cell focal 1138 mean); D. Phaeopigment concentration $(\mu \mathrm{g} / \mathrm{g})$; Bay of Plenty, surface sediment $(0-1 \mathrm{~cm})$ : E. 1139 Surface chlorophyll concentration $\left(\mathrm{mg} \mathrm{m}^{-3}\right)$; F. Plan curvature; Subsurface sediment $(1-5 \mathrm{~cm}): \mathrm{G}$. 1140 Organic carbon content $(\% \mathrm{OC})$; H. Kurtosis. (See Table 4 and Table 6 for results of DistLM 1141 analyses). 
Hikurangi Margin
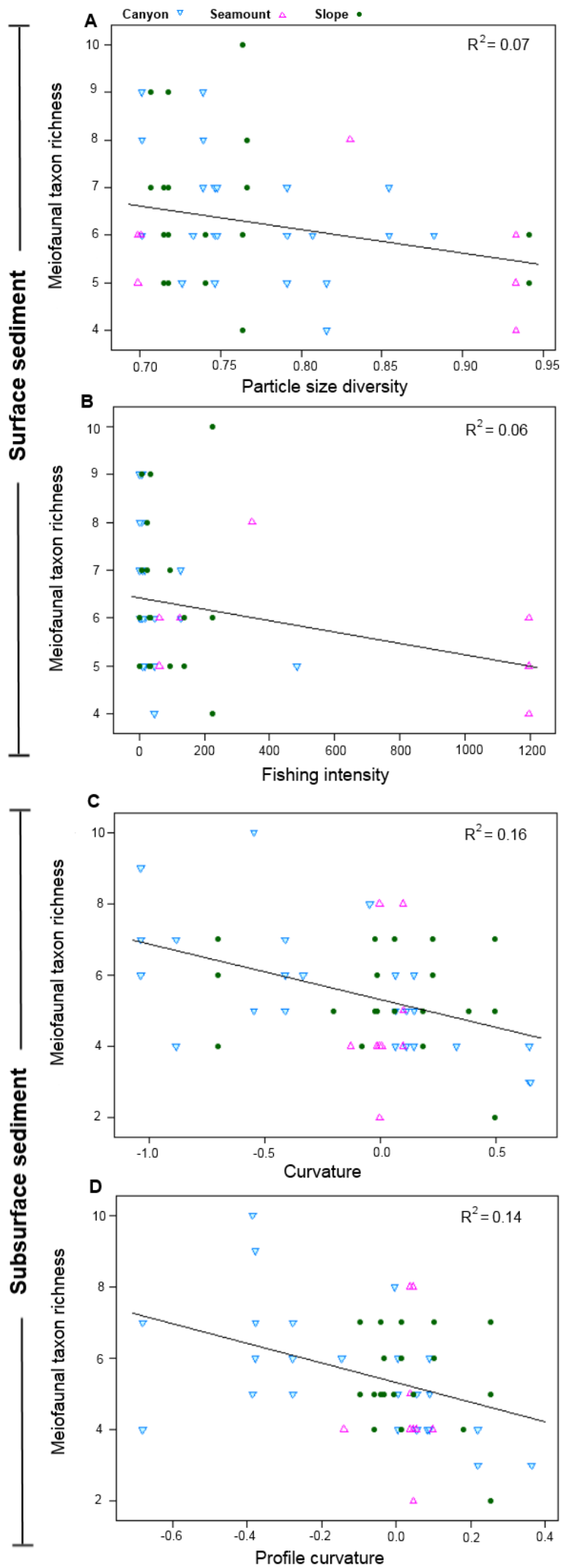

Bay of Plenty
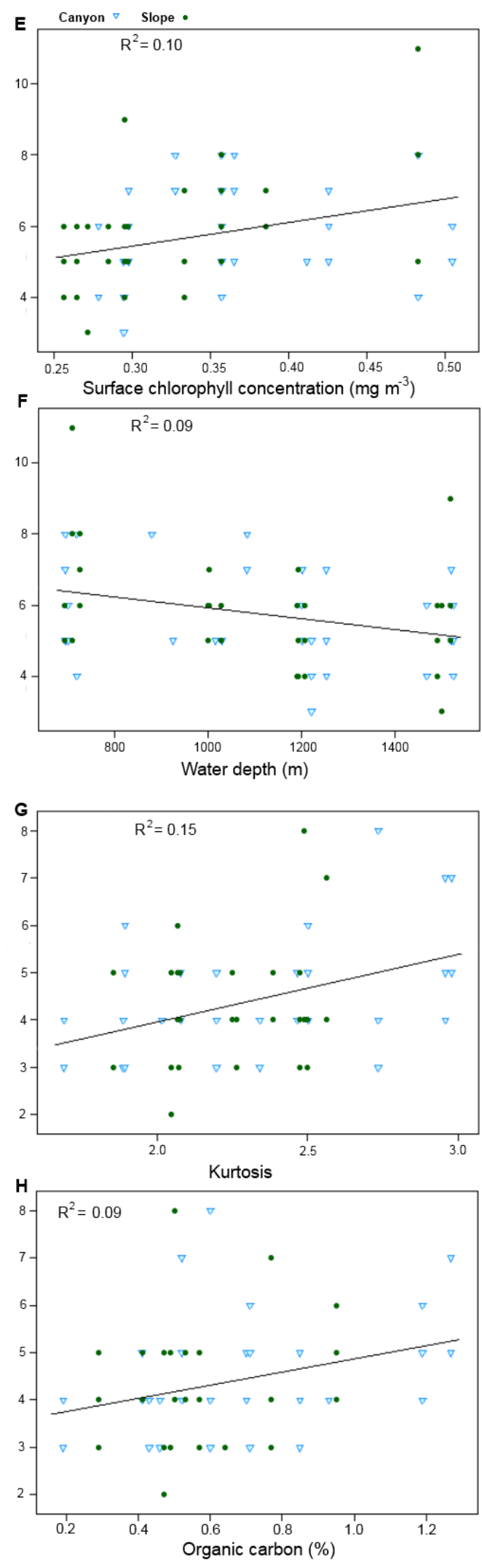
1143 Figure 7. Selection of statistically significant $(\mathrm{P}<0.05)$ correlations between environmental 1144 variables and meiofaunal diversity at different sediment layers in the Hikurangi Margin and Bay 1145 of Plenty study regions. Hikurangi Margin, surface sediment $(0-1 \mathrm{~cm})$ : A. Particle size diversity; 1146 B. Fishing intensity (num. of trawls); Subsurface sediment (1-5 cm): C. Curvature; D. Profile 1147 curvature; Bay of Plenty, surface sediment $(0-1 \mathrm{~cm})$ : E. Surface chlorophyll concentration $\left(\mathrm{mg} \mathrm{m}^{-}\right.$ 1148 3); F. Water depth (m); Subsurface sediment (1-5 cm): G. Kurtosis; H. Organic carbon content. 1149 (See Table 4 and Table 6 for results of DistLM analyses).

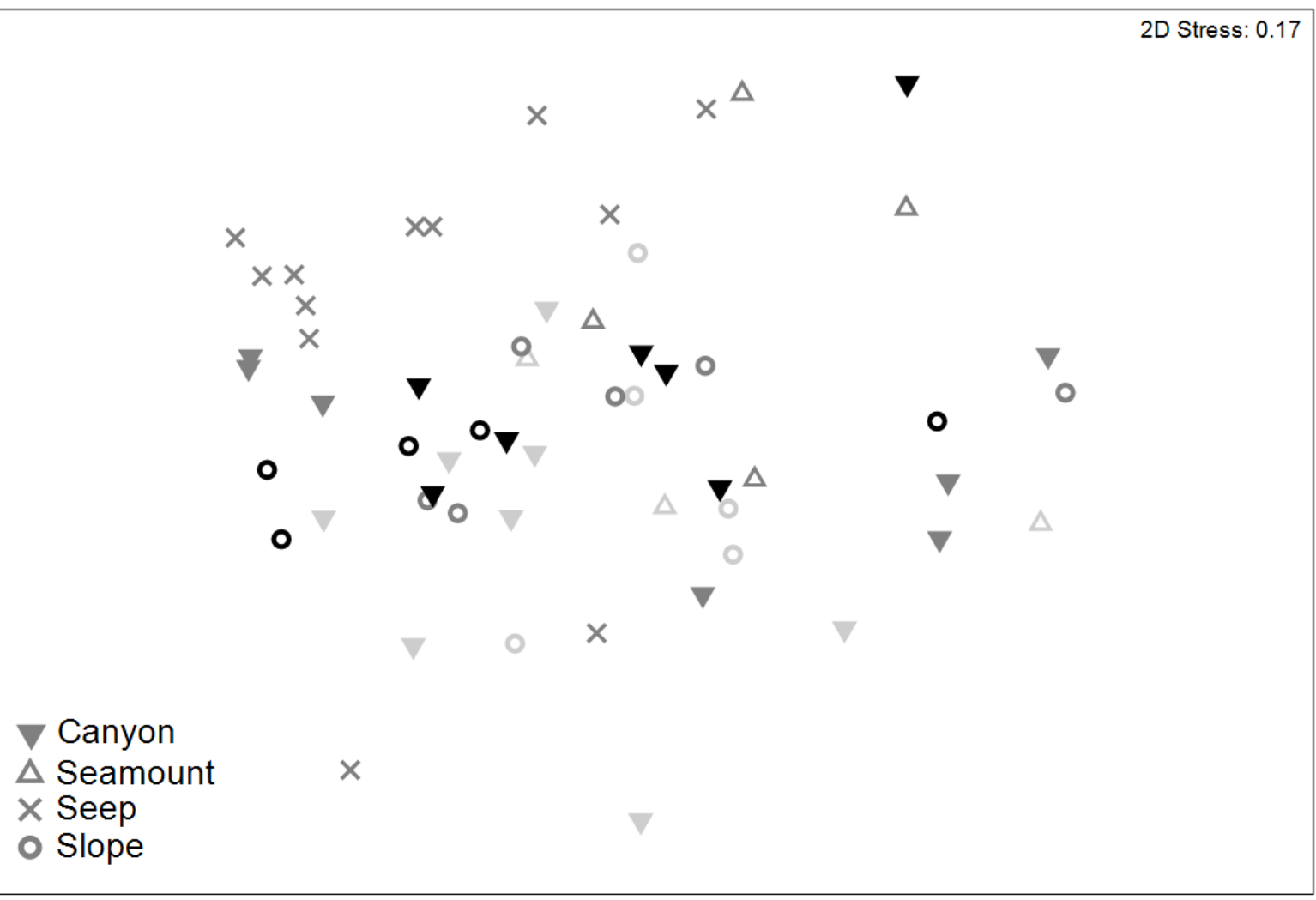

Figure 8. Two-dimensional MDS ordination of meiofaunal community structure for habitats in the Hikurangi Margin study region (water depth: 700-1200 m only). Depth strata are shown by shades of grey ranging from light grey $(700 \mathrm{~m})$ to black $(1200 \mathrm{~m})$. 